\title{
PARVODICIN, A NOVEL GLYCOPEPTIDE FROM A NEW SPECIES, ACTINOMADURA PARVOSATA: DISCOVERY, TAXONOMY, ACTIVITY AND STRUCTURE ELUCIDATION
}

\author{
Siegrried B. Christensen, H. S. Allaudeen, Michael R. Burke, Steven A. Carr, \\ S. K. Chung, Peter DePhillips, John J. Dingerdissen, Michael DiPaolo, \\ Albert J. Giovenella, Sarah L. Heald, Lewis B. Killmer, Bruce A. Mico, \\ luciano Mueller, Charles H. Pan, Benjamin L. Poehland, \\ James B. Rake, Gerald D. Roberts, Marcia C. Shearer, \\ Robert D. Sitrin, Louis J. Nisbet and Peter W. JefFs \\ Research and Development Division, Smith Kline \& French Laboratories, \\ P.O. Box 1539, King of Prussia, Pennsylvania 19406-0939, U.S.A.
}

(Received for publication January 12, 1987)

\begin{abstract}
An extensive taxonomic investigation identified strain SK\&F-AAJ-271 as a new species, designated Actinomadura parvosata. Fermentations of this organism produce a complex of acidic, lipophilic glycopeptide antibiotics, the parvodicins. Structures for seven of the isolated components were derived from a combination of mass spectral, high-field NMR and chemical techniques. The $O$-acetyl functionality present in two of the isolated components is a structural feature unique among the known members of this class of antibiotics. The parvodicins are active in vitro against a range of Gram-positive bacteria. The most active parvodicin, $\mathrm{C}_{1}$, produces high serum levels in vivo and has the potential for a long duration of action.
\end{abstract}

The increasing importance of vancomycin for the treatment of methicillin-resistant staphylococcal infections ${ }^{1,2}$ has stimulated the search for novel members of this class of glycopeptide antibiotics. Central to our effort in this area has been a mechanism-based screen ${ }^{32}$ in which a mimetic of the bacterial cell wall receptor ${ }^{4)}$ for glycopeptides is used to antagonize selectively the activity of these antibiotics in the complex mixture of culture products, the implementation of efficient isolation and purification procedures, ${ }^{5,8)}$ as well as the development of fast atom bombardment mass spectrometry (FAB-MS) techniques ${ }^{7)}$ and modern two-dimensional (2D) NMR methods ${ }^{8)}$ for structural characterization. This strategy has led to the discovery, isolation and structure elucidation of the aridicins, ${ }^{8 \sim 10)}$ the kibdelins ${ }^{11,12)}$ and as reported in detail here, the parvodicins. ${ }^{13}$ )

\section{Materials and Methods}

Chemotaxonomy, Physiological and Biochemical Evaluation

Strain SK\&F-AAJ-271 was isolated from a soil sample collected on the shore of a pond or stream near Myittanyunt, Burma. Because SK\&F-AAJ-271 sporulates poorly, the culture was grown in shake flasks and maintained as frozen stock in a mechanical freezer at $-70^{\circ} \mathrm{C}$ or in the vapor phase of liquid nitrogen. Slant cultures were maintained on thin inorganic salts - starch agar (Difco inorganic salts - starch agar (ISP 4) $12 \mathrm{~g}$, Difco Bactoagar $15 \mathrm{~g}$, distilled water (1 liter) supplemented with yeast extract $(2 \mathrm{~g} /$ liter $)$ ). Morphological observations were made on plates of modified thin inorganic salts starch agar (Difco inorganic salts - starch agar (ISP 4) $12 \mathrm{~g}$, Difco Bactoagar $15 \mathrm{~g}$, distilled water $800 \mathrm{ml}$, soil extract $200 \mathrm{ml}$, thiamine hydrochloride $0.5 \mathrm{mg}$, biotin $0.25 \mathrm{mg}$ ). Color descriptions were chosen by comparison to color chips from the ISCC-NBS Color Charts ${ }^{14}$ or the Methuen Handbook of 
Colour. ${ }^{15)}$

A Jeol T300 scanning electron microscope was used for microscopic evaluation. Coverslip cultures, prepared by the method of KAWATO and SHINOBU, ${ }^{16)}$ were fixed in glutaraldehyde, post-fixed with osmium tetroxide, critical point dried and sputter coated with gold.

Purified cell preparations were analyzed by the methods of BECKER et al. ${ }^{17}$ ) Whole-cell hydrolysates and cell wall phospholipids were examined using the techniques of LECHEVALIER ${ }^{18)}$ and LECHEVALIER et al. ${ }^{19)}$ respectively.

The physiological and biochemical tests used to characterize SK\&F-AAJ-271 were those of GORDON $^{20,21)}$, GORDON and MiHM, ${ }^{22)}$ and GOODFELLOW et al. ${ }^{23)}$ The tests used to determine melanoid pigments were those of SHIRLING and GotTlieb. ${ }^{24}$ Phosphatase activity was determined by the methods of Kurup and SCHMItT. ${ }^{25)}$ The modified carbon utilization medium of PRIDHAM and GoTTLIEB (ISP 9) ${ }^{26)}$ proved unsuitable for the characterization of SK\&F-AAJ-271. The medium used to determine sole carbon source utilization was the C-2 medium of NONOMURA and OHARA. ${ }^{27)}$

Susceptibility of SK\&F-AAJ-271 to antibiotics was examined by placing BBL susceptibility disks on nutrient agar plates seeded with SK\&F-AAJ-271. Plates were held at $4^{\circ} \mathrm{C}$ for 1 hour to permit diffusion of the antibiotics. Diameters of the zones of inhibition were measured after incubation for 1 week at $28^{\circ} \mathrm{C}$.

\section{High Performance Liquid Chromatography (HPLC) Assay of Parvodicins}

$\mathrm{A} \mathrm{C}_{18}$ Sep-Pak cartridge (Waters Associates) was used for pretreatment of broth samples and crude extracts. All other samples were analyzed directly. HPLC analyses ${ }^{28)}$ of samples were conducted on a Beckman 345 binary liquid chromatograph using an Altex Ultrasphere-ODS column (5 $\mu \mathrm{m}, 4.6$ i.d. $\times 150 \mathrm{~mm}$ ) with detection at $220 \mathrm{~nm}$. Analyses were performed using: a) $14 \rightarrow 37 \%$

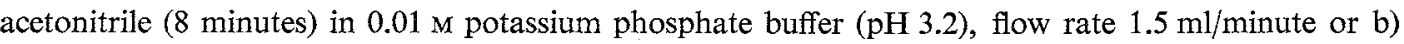
$30 \%$ acetonitrile ( 1 minute), then $30 \rightarrow 35 \%$ acetonitrile ( 15 minutes) in $0.01 \mathrm{~m}$ potassium phosphate buffer (pH 3.2), flow rate $1.5 \mathrm{ml} /$ minute.

Fermentation

A 14-day old agar slant of $A$. parvosata dispersed in $10 \mathrm{ml}$ of sterile water was used to inoculate $500 \mathrm{ml}$ of seed medium $13 \mathrm{H}^{9)}$ contained in a 4-liter aspirator bottle. After incubation at $28^{\circ} \mathrm{C}$ on a rotary shaker (New Brunswick Model G53) at $250 \mathrm{rpm}$ ( $5 \mathrm{~cm}$ throw) for 4 days, the first seed was transferred to 15 liters of seed medium $13 \mathrm{H}$ in a 20 -liter fermentor which was maintained at $28^{\circ} \mathrm{C}$, aerated at $0.4 \mathrm{vvm}$ and agitated at $300 \sim 400 \mathrm{rpm}$. After 4 days, 5 liters of the second seed were transferred to 50 liters of seed medium $13 \mathrm{H}$ contained in a 75 -liter Chemap fermentor. This third seed, incubated at $28^{\circ} \mathrm{C}$, aerated at $0.5 \mathrm{vvm}$ and agitated at $250 \sim 300 \mathrm{rpm}$ for 4 days, was inoculated into 500 liters of production medium $\mathrm{E} 1$ (glucose $20 \mathrm{~g}$, soy peptone $10 \mathrm{~g}$, yeast extract $1 \mathrm{~g}, \mathrm{CaCO}_{3} 1 \mathrm{~g}$ and $\mathrm{CoCl}_{2}$ $0.001 \mathrm{~g}$ in 1 liter of distilled water) contained in a 750-liter ABEC fermentor. This production stage was incubated at $28^{\circ} \mathrm{C}$, aerated at $0.3 \mathrm{vvm}$ and agitated at $120 \mathrm{rpm}$. Production of parvodicin $\mathrm{C}_{1}$, measured by analytical reversed-phase HPLC (RPHPLC), peaked at $60 \mu \mathrm{g} / \mathrm{ml}$ by 90 hours. This was accompanied by a decline in the level of parvodicin $\mathrm{C}_{3}$, which was the major component observed earlier in the fermentation.

Isolation and Purification of the Parvodicin Complex

A: The crude fermentation broth ( $c a .600$ liters) was clarified by rotary drum filtration (KomlineSanderson, Laboratory Scale Model) using Hyflo Supercell (Johns-Manville Products Corp.). After the filtrate (400 liters) was chilled $\left(4^{\circ} \mathrm{C}\right), 40$ liters of IRA-68 anion exchange resin (Rohm and Haas) was added with stirring and with continuous addition of concentrated hydrochloric acid to maintain the $\mathrm{pH}$ between 6 and 8 . The resin was allowed to settle, the broth was decanted and the resin was washed twice with water (40 liters). The complex was batch-eluted with ammonium hydroxide ( $1 \mathrm{M}, 270$ liters). The solution was neutralized with concentrated phosphoric acid and applied to two columns ( 8 liters) of Diaion HP-20 resin (Mitsubishi Chem. Inc.). Each column was washed with water (20 liters) and the complex was eluted with $60 \%$ acetonitrile in water (20 liters). The combined eluates were concentrated in vacuo to 10 liters, which was treated in 1 liter portions with Affigel-10-D-Ala-D-Ala 
$(300 \mathrm{ml})_{.}^{6,28)}$ The gel was washed with sodium phosphate buffer $(0.02 \mathrm{M}, \mathrm{pH} 7,1$ liter $)$ and the complex was eluted with $600 \mathrm{ml}$ of $50 \%$ acetonitrile in ammonium hydroxide $(0.1 \mathrm{M})$. The combined eluates were neutralized with phosphoric acid, diluted to $c a .10 \%$ acetonitrile and applied to Diaion HP-20 resin. After the water wash, elution and concentration as described above, lyophilization of the concentrate yielded $4 \mathrm{~g}$ of solid.

Isolation of the individual components was effected by preparative RPHPLC of portions of the crude complex on a Vydac C18 column (HP Chemicals, 5.1 i.d. $\times 50 \mathrm{~cm}, 15 \sim 20 \mu \mathrm{m}, 300 \mathrm{~A}$ ) using a gradient of acetonitrile $(15 \rightarrow 20 \%, 10$ minutes; $20 \rightarrow 24 \%, 17$ minutes; $24 \rightarrow 25 \%, 48$ minutes $)$ in potassium phosphate buffer $(0.01 \mathrm{M}, \mathrm{pH} 6.0)$ at a flow rate of $100 \mathrm{ml} /$ minute with detection at $280 \mathrm{~nm}$, as shown for a typical $650 \mathrm{mg}$ load in Fig. 2. Upon completion of the chromatographic runs, like fractions were pooled and desalted on Diaion HP-20 resin to yield parvodicins A (16 mg), $B_{1}(28 \mathrm{mg}), B_{2}$ (68 mg), $\mathrm{C}_{1}(300 \mathrm{mg})$ and $\mathrm{C}_{2}(230 \mathrm{mg})$.

B: A portion of fermentation broth (15 liters) was clarified by filtration with Celite and the filtrate (11 liters) was applied to a column (4 liters) of Diaion HP-20 resin. The column was washed with water (20 liters) and the complex was eluted with $60 \%$ acetonitrile in water (10 liters). The eluate was concentrated in vacuo to 3 liters and applied in two portions to a column ( $200 \mathrm{ml})$ of Affigel-10-D-AlaD-Ala. $\left.{ }^{8}, 2 \theta\right)$ Each column was washed with sodium phosphate buffer $(0.02 \mathrm{M}, \mathrm{pH} 7.0,1$ liter $)$ and water $(400 \mathrm{ml})$ prior to elution of the complex with $50 \%$ acetonitrile in ammonium hydroxide $(0.1 \mathrm{M}, 500 \mathrm{ml})$. The eluates were neutralized immediately with dilute hydrochloric acid, combined and lyophilized.

The crude complex was chromatographed on a Whatman Magnum 20 column $(2.2$ i.d. $\times 50 \mathrm{~cm})$ packed with Whatman Partisil-10 ODS-3 using a step-gradient of acetonitrile in potassium phosphate buffer $(0.1 \mathrm{M}, \mathrm{pH} 3.2)$ at a flow rate of $15 \mathrm{ml} /$ minute with detection at $280 \mathrm{~mm}$. The individual components eluted at $29 \%$ acetonitrile. Like fractions were pooled, diluted with six volumes of water and applied to Diaion HP-20 resin. After washing with water, the components were eluted with $60 \%$ acetonitrile in water. The acetonitrile was removed in vacuo and the water by lyophilization to yield components $\mathrm{C}_{1}(24 \mathrm{mg}), \mathrm{C}_{2}(6 \mathrm{mg}), \mathrm{C}_{3}(8 \mathrm{mg})$ and $\mathrm{C}_{4}(4 \mathrm{mg})$. In a similar isolation procedure conducted subsequently, the affinity-bound complex was eluted with $5 \%$ acetonitrile in water (1 liter) prior to elution of the bulk of the complex with $50 \%$ acetonitrile in ammonium hydroxide. This eluate was desalted and lyophilized, providing a sample of complex $(125 \mathrm{mg})$ enriched in minor components (RPHPLC determination).

\section{General Procedures}

Isoelectric focusing was performed using an LKB Multiphase apparatus and activity against Bacillus subtilis ATCC 6633 for detection. ${ }^{30)}$ Carbohydrate analysis and UV spectroscopy were conducted as described previously. ${ }^{10)}$ FAB-MS data was obtained with a VG Analytical ZAB-1F mass spectrometer equipped with a high-field magnet using thioglycerol-oxalic acid as solvent matrix. ${ }^{7)}{ }^{1} \mathrm{H}$ NMR data was obtained at $500.1 \mathrm{MHz}$ using a Jeol GX500 spectrometer, utilizing the techniques described in detail elsewhere. ${ }^{\text {s) }}$

\section{Aglycone Production}

A sample of Affigel-isolated complex enriched in minor components $(105 \mathrm{mg})$ was dissolved in $5 \mathrm{ml}$ of a solution of hydrochloric acid $(0.3 \mathrm{M})$ in $10 \%$ aqueous dimethylsulfoxide. The mixture was heated under nitrogen at $100 \sim 105^{\circ} \mathrm{C}$ for 75 minutes, cooled to room temp and concentrated in vacuo; RPHPLC analysis revealed two species present in a 4 to 1 ratio. After a standard course of affinity chromatography, the isolated material was subjected to semi-preparative RPHPLC (Partisil-10 ODS-3, Magnum 20, 2.2 i.d. $\times 50 \mathrm{~cm})$ using an isocratic system of acetonitrile $(17 \%)$ in potassium phosphate buffer $(0.01 \mathrm{M}, \mathrm{pH} 6.0)$ at a flow rate of $10 \mathrm{ml} /$ minute with detection at $220 \mathrm{~nm}$. Like fractions were pooled and desalted (HP-20) to yield aglycone I ( $26 \mathrm{mg}$; isoelectric point $5.3 ; \mathrm{E}_{1 \mathrm{em}}^{1 \%}\left(280 \mathrm{~nm} ; \mathrm{CH}_{3} \mathrm{CN}\right.$ $\left.\left.\mathrm{H}_{2} \mathrm{O}, 1: 1\right) 68\right)$ and aglycone II (5 mg; isoelectric point 5.3; $\left.\mathrm{E}_{\mathrm{lcm}}^{1 \%}\left(280 \mathrm{~nm} ; \mathrm{CH}_{3} \mathrm{CN}-\mathrm{H}_{2} \mathrm{O}, 1: 1\right) 70\right)$.

\section{Pseudoaglycone Production}

A mixture of components $C_{1}$ and $C_{2}(2.5 \mathrm{~g}$, isolated by preparative RPHPLC) was dissolved in $50 \%$ aqueous acetonitrile $(160 \mathrm{ml})$ and the apparent $\mathrm{pH}$ was adjusted to 3 with hydrochloric acid. The 
mixture was heated at reflux for 20 hours, cooled to room temp and concentrated in vacuo. The product was subjected to a standard course of affinity chromatography and desalting, yielding $1.8 \mathrm{~g}$. A portion ( $250 \mathrm{mg}$ ) of this was chromatographed and desalted as described for the aglycones to provide the mannosyl aglycone $\left(131 \mathrm{mg}\right.$; isoelectric point $\left.5.2 ; \mathrm{E}_{1 \mathrm{~cm}}^{19}\left(280 \mathrm{~nm} ; \mathrm{CH}_{3} \mathrm{CN}-\mathrm{H}_{2} \mathrm{O}, 1: 1\right) 70\right)$.

\section{Fatty Acid Analysis}

Acidic methanolysis of individual components was conducted and the derived fatty acid methyl esters were identified by comparisons with the gas chromatography mass spectrometry (GC-MS) data obtained from standards as described previously ${ }^{12,31)}$ using a DB-17 fused silica capillary column $(0.25 \mathrm{~mm}$ i.d. $\times 15 \mathrm{~m})$ temperature-programed from a) 75 to $250^{\circ} \mathrm{C}$ at a rate of $12^{\circ} \mathrm{C} /$ minute or b) 90 to $275^{\circ} \mathrm{C}$ at a rate of $10^{\circ} \mathrm{C} /$ minute (see Table 2).

Antimicrobial Activity

In vitro (MIC, $\mu \mathrm{g} / \mathrm{ml})$ activity was determined using methods described previously. ${ }^{9}$

Pharmacokinetic Studies

The pharmacokinetics of parvodicin $\mathrm{C}_{1}$ were determined by means of techniques described in detail elsewhere ${ }^{322}$ except that serum concentrations of antibiotic were determined also at $480,960,1,080$ and 1,440 minutes after drug administration.

\section{Results}

\section{Morphological and Cultural Characteristics}

Strain SK\&F-AAJ-271 has the general morphological features that were described by LECHEVALIER and LECHEVALIER ${ }^{337}$ for the genus Actinomadura. It is a Gram-positive, filamentous organism that formed a substrate mycelium and, on a few media, an aerial mycelium. No motile elements were observed in either the aerial or substrate mycelium.

The substrate mycelium was well-developed with moderately to densely branched, long hyphae that were approximately 0.5 to $1.0 \mu \mathrm{m}$ in diameter. No spores were produced on the substrate mycelium and mycelial fragmentation was never observed.

The aerial mycelium produced long, branching aerial hyphae that bore chains of spores following five to seven weeks incubation on modified thin inorganic salts - starch agar. Chains of more than 30 spores were common, but short chains of ten spores or less were also usually present. A few of the spore chains appeared to be sessile but most were borne on short to relatively long sporophores. An occasional spore chain was hooked, irregularly curved or formed a tightly closed spiral that resembled a pseudo-sporangium. The most common spore chain morphology, however, was one in which the upper half to two-thirds of the spore chain formed a spiral of two to six turns. These spirals could be very regular and open or tightly closed. The spirals could also be somewhat irregular and have a knotlike appearance. The spores varied in size and shape (round to almost square), particularly when only a few tufts of spore-bearing hyphae were produced following prolonged incubation on suboptimal media. On modified thin inorganic salts - starch agar, a typical spore was smooth-walled, ovoid to rectangular, and approximately 0.5 to $2.5 \mu \mathrm{m}$ long and 0.5 to $1.3 \mu \mathrm{m}$ in diameter.

Plates for the determination of cultural characteristics of SK\&F-AAJ-271 were incubated at $28^{\circ} \mathrm{C}$ in closed petri dish cans and observed at intervals up to 21 days. As summarized in Table 1, the substrate mycelium of SK\&F-AAJ-271 varied from yellow-brown to orange to purple. The aerial mycelium was white to pink. Soluble pigments varied from yellow-brown to orange to violet-red. In yeast extract - malt extract agar and oatmeal agar, the reverse side pigments and soluble pigments were affected by $\mathrm{pH}$. 
Table 1. Cultural characteristics of SK\&F-AAJ-271.

\begin{tabular}{|c|c|c|}
\hline Medium & & Growth and morphology \\
\hline \multirow{3}{*}{$\begin{array}{l}\text { Yeast extract - malt extract } \\
\text { agar (ISP 2) }\end{array}$} & $\mathrm{G}$ : & Excellent, violet-red to dark reddish brown \\
\hline & AM: & None to sparse, white, sterile \\
\hline & SP: & Dark reddish orange to strong reddish brown \\
\hline \multirow[t]{3}{*}{ Oatmeal agar (ISP 3) } & $\mathrm{G}:$ & $\begin{array}{l}\text { Good, dark reddish brown (Methuen } 10 \text { E6 violet-brown) to } \\
\text { violet-red (Munsell } 10 \mathrm{R} / \mathrm{P} 6 / 6 \text { ) }\end{array}$ \\
\hline & AM: & Sparse, white, sterile \\
\hline & SP: & Pale reddish brown to violet-red \\
\hline \multirow{3}{*}{$\begin{array}{l}\text { Inorganic salts - starch } \\
\text { agar (ISP 4) }\end{array}$} & G: & Fair to good, yellow-brown to light orange \\
\hline & AM: & None \\
\hline & SP: & Pale orange \\
\hline \multirow{2}{*}{$\begin{array}{l}\text { Modified thin inorganic } \\
\text { salts - starch agar }\end{array}$} & G: & Good, yellow-brown to light orange \\
\hline & $\begin{array}{l}\text { AM: } \\
\text { SP: }\end{array}$ & $\begin{array}{l}\text { None to sparse, white, spores none to sparse } \\
\text { None }\end{array}$ \\
\hline \multirow[t]{3}{*}{$\begin{array}{l}\text { Glycerol - asparagine } \\
\text { agar (ISP 5) }\end{array}$} & G: & $\begin{array}{l}\text { Fair to good, yellow-brown to reddish brown (ICSS-NBS } 43 \text {, } \\
\text { moderate reddish brown) }\end{array}$ \\
\hline & AM: & Moderate white bloom, sterile \\
\hline & SP: & Pale yellow-brown, variably present \\
\hline \multirow[t]{3}{*}{ GAUZE's mineral agar I } & $\mathrm{G}:$ & Fair to good, yellow-brown \\
\hline & AM: & None to sparse, white, sterile \\
\hline & SP: & None \\
\hline \multirow[t]{3}{*}{ GAUZE's organic agar 2} & $\mathrm{G}:$ & Fair, reddish orange (ISCC-NBS 35, strong reddish orange) \\
\hline & AM: & None \\
\hline & SP: & None \\
\hline \multirow{3}{*}{$\begin{array}{l}\text { Peptone - yeast extract - iron } \\
\text { agar (ISP 6) }\end{array}$} & G: & Fair, yellow-brown \\
\hline & AM: & None \\
\hline & SP: & None \\
\hline \multirow[t]{3}{*}{$\begin{array}{l}\text { Glucose - yeast extract agar } \\
\text { (ISP 6) }\end{array}$} & $\mathrm{G}:$ & $\begin{array}{l}\text { Fair to good, yellow-brown to brownish orange } \\
\text { (ICSS-NBS 54) }\end{array}$ \\
\hline & AM: & None \\
\hline & SP: & None \\
\hline \multirow[t]{3}{*}{ Synthetic agar } & G: & $\begin{array}{l}\text { Poor to fair, orange (ISCC-NBS } 48 \text {, vivid orange to ISCC- } \\
\text { NBS } 50 \text {, strong orange) }\end{array}$ \\
\hline & AM: & None \\
\hline & SP: & None \\
\hline \multirow[t]{3}{*}{ C-2 agar with glucose } & $\mathrm{G}:$ & $\begin{array}{l}\text { Good, violet-red to purple (ISCC-NBS } 243 \text {, very dark reddish } \\
\text { purple) }\end{array}$ \\
\hline & AM: & Moderate, white to pale pink, sterile \\
\hline & SP: & $\begin{array}{l}\text { Pale lavender to purplish red (ISCC-NBS 262, grayish purplish } \\
\text { red) }\end{array}$ \\
\hline
\end{tabular}

a G: Growth of substrate mycelium, AM: aerial mycelium, SP: soluble pigment.

\section{Chemotaxonomy, Physiological and Biochemical Characteristics}

Purified cell wall preparations contained meso-diaminopimelic acid, alanine, glutamic acid, glucosamine, muramic acid, a major amount of glucose and a trace of mannose. Whole-cell hydrolysates contained galactose, glucose, mannose, ribose and madurose. Phospholipids present were phosphatidyl ethanolamine, phosphatidyl methylethanolamine, diphosphatidyl glycerol, phosphatidyl inositol, traces of phosphatidyl inositol mannosides and an unknown glucosamine-containing phospholipid. Thus, SK\&F-AAJ-271 has a type III cell wall with a type B sugar pattern ${ }^{34)}$ and a phospholipid pattern of type PIV. ${ }^{193}$

The organism does not grow under anaerobic conditions. Temperature range for growth was 
15 to $45^{\circ} \mathrm{C}$; growth at 15 and $45^{\circ} \mathrm{C}$ usually was poor. The following tests were positive: reduction of nitrate to nitrite; hydrolysis of adenine $(0.5 \%)$, casein, elastin, gelatin, hypoxanthine and L-tyrosine; decomposition of allantoin, arbutin, esculin and urea; production of catalase, phosphatase, deoxyribonuclease and ribonuclease. Hydrolysis of starch was weak and partial. Decomposition of hippurate was positive following prolonged incubation ( 8 weeks). Hydrogen sulfide production was weakly positive. Negative results were obtained for: production of melanin; liquefaction of gelatin; hydrolysis of cellulose (Avicel) and xanthine. No growth occurred in lysozyme broth or in $4 \% \mathrm{NaCl}$. SK\&FAAJ-271 was resistant to discs containing rifampicin $(5 \mu \mathrm{g})$ and benzylpenicillin $(10 \mathrm{U})$.

Acid was produced from adonitol, L-arabinose, D-cellobiose, dextrin, glucose, D-fructose, Dgalactose, glycerol, $i$-inositol, inulin, lactose, maltose, D-mannitol, D-mannose, melibiose, $\alpha$-methylD-glucoside, $\alpha$-methyl-D-mannoside, raffinose, rhamnose, D-ribose, salicin, D-sorbitol, starch, sucrose, trehalose and D-xylose. No acid was produced from dulcitol, $i$-erythritol, $\mathrm{D}$-melezitose and L-sorbose. Citrate, malate, succinate, oxalate, lactate, acetate, pyruvate and formate were utilized; benzoate, propionate, tartrate and mucate were not utilized.

On the C-2 medium of NonOMura and OHARA, ${ }^{27)}$ SK\&F-AAJ-271 utilized adonitol, L-arabinose, D-cellobiose, glucose, D-fructose, D-galactose, $i$-inositol, D-mannitol, raffinose, rhamnose, salicin, sucrose and D-xylose as sole carbon sources; inulin was poorly utilized. The vitamins in this medium were not essential for the growth of SK\&F-AAJ-271, but they did enhance substrate mycelium growth and pigment production.

\section{Identification and Classification}

The description of SK\&F-AAJ-271 was compared with those of the Actinomadura species listed on the Approved Lists of Bacterial Names. The type cultures of those species having a red, reddish brown or violet-red substrate mycelium with a pink aerial mycelium (Actinomadura luzonensis ATCC 31491, Actinomadura roseola ATCC 33579, Actinomadura roseoviolacea ATCC 27297, Actinomodura rubra ATCC 27031, Actinomadura salmonea ATCC 33580, Actinomadura vinacea ATCC 33581) were grown on a series of 15 media used in the morphological characterization of SK\&F-AAJ-271. These direct comparisons of morphology and color, along with biochemical and physiological data from the taxonomic literature, permitted easy differentiation of A. luzonensis, A. roseoviolacea, A. roseola, A. rubra, A. salmonea and $A$. vinacea from SK\&F-AAJ-271.

$A$. roseola and $A$. vinacea both produce spore chains which are straight, hooked or slightly wavy. The spore surface of these two species is warty. ${ }^{35)} A$. roseoviolacea produces spore chains which are predominantly tightly closed spirals that form pseudo-sporangia. On peptone - yeast extract - iron agar, A. roseoviolacea produces a reddish black to black substrate mycelium, no aerial mycelium and a grayishreddish brown soluble pigment. A. roseoviolacea is resistant to lysozyme and does not degrade adenine or elastin. ${ }^{23)}$ It neither grows in the presence of $0.4 \%$ adenine nor produces allantoinase or urease. ${ }^{36)}$

A. luzonensis produces only pale orange-yellow to yellow-brown soluble pigments and does not utilize sucrose, raffinose or salicin as sole carbon sources. ${ }^{37)}$ A. rubra is a much more intensely pigmented culture than SK\&F-AAJ-271. On oatmeal agar (ISP 3), yeast extract-malt extract agar (ISP 2), GAUZE's mineral agar I and glucose - yeast extract agar, A. rubra produces a bright reddish orange to dark reddish brown substrate mycelium with a bright red-orange to scarlet soluble pigment. In addition, $A$. rubra does not produce allantoinase or urease. ${ }^{36)}$ 
Of the six cultures compared directly with SK\&F-AAJ-271, the spore chains of A. salmonea most closely resembled those found in SK\&F-AAJ-271. The spore surface of $A$. salmonea, however, was warty. ${ }^{35)}$ On synthetic agar, $A$. salmonea grew poorly and the substrate mycelium was translucent to pale yellow-brown, with no aerial mycelium or soluble pigment present. A. salmonea neither produced allantoinase or urease nor degraded ribonucleic acid or L-tyrosine. ${ }^{36)}$

Our efforts to obtain Actinomadura carminata for comparative taxonomic purposes were unsuccessful. However, patent literature indicates ${ }^{38}$ that $A$. carminata formed spore chains arranged monopodially along the hyphae that, more often than not, were twisted in a tightly closed spiral, doughnut or dense ball. The number of spores per chain was 6 to 14 and the spores were round and smoothwalled. On yeast extract - malt extract agar (ISP 2), A. carminata produced a brownish violet substrate mycelium, a well-developed, fluffy pink aerial mycelium and no soluble pigment. Taxonomic literature $^{39}$ ) indicates that the spore chains of $A$. carminata were predominantly tightly closed spirals that were embedded in slime to form pseudo-sporangia. On oatmeal agar, growth of $A$. carminata was good with a pale lilac to reddish lilac to red-violet substrate mycelium, a well-developed pink aerial mycelium and a weak soluble pigment. On GAUZE's organic agar 2, A. carminata produced a brownish violet or blackish violet substrate mycelium with no aerial mycelium or soluble pigment. Thus, SK\&FAAJ-271 was readily distinguishable from $A$. carminata on the basis of spore chain morphology and length, as well as pigmentation and growth characteristics on various media.

Strain SK\&F-AAJ-271 is therefore regarded as a new species of the genus Actinomadura for which we propose the name Actinomadura parvosata ( parvus L. adj., small in number; satus L. adj., seeded). The specific epithet refers to the few, if any, spores produced by this culture on media normally used to characterize actinomycetes. Strain SK\&F-AAJ-271, the type strain of A. parvosata, has been deposited in the American Type Culture Collection, Rockville, MD, under the accession number ATCC 53463.

\section{Production and Isolation of the Parvodicins}

Production-stage fermentations of $A$. parvosata were conducted under conditions similar to those reported previously for Kibdelosporangium aridum. ${ }^{\ominus, 11}$ ) Antibiotic production, which was coincident with a purple pigmentation of the broth, occurred during growth and peaked by 4 days, declining after biomass had reached a maximum.

Partially-purified samples of the A. parvosata fermentation broth, examined by RPHPLC and isoelectric focusing, ${ }^{30}$ ) contained a complex of at least ten lipophilic components of low isoelectric point (3.8). The two major components were designated $C_{1}$ and $C_{3}$ on the basis of their RPHPLC retention times relative to those of the aridicin " $\mathrm{C}$ " components ${ }^{10)}$ (Fig. 1a); the remaining components were denoted analogously. Upon repeated analysis of samples collected during the course of the fermentation, it was observed that the level of components $C_{3}$ and $C_{k}$ in each sample decreased with a concomitant increase in the level of components $C_{1}$ and $C_{2}$. This apparent conversion was accelerated by brief treatment of the samples with base (Fig. 1b), and was accompanied by an increase in the in vitro biological activity of the antibiotic complex. Consequently, two similar but distinct isolation schemes were followed.

The primary isolation procedure began with adsorption of the complex from clarified broth onto the weak anion exchange resin IRA-68, followed by elution with dilute ammonium hydroxide; this step was necessitated by the low fermentation titer. The neutralized eluate was desalted and subjected to a standard course of Diaion HP-20 and Affigel-10-D-Ala-D-Ala ${ }^{6}{ }^{29}$ chromatography. Concentra- 
tion of the Affigel eluate using Diaion HP-20 resin provided $4 \mathrm{~g}$ of solid material containing primarily components $A, B_{1}, B_{2}, C_{1}$ and $C_{2}$.

While analytical RPHPLC separation ${ }^{28)}$ of these components was achieved routinely, attempted scale-up to a large-particle $(>40 \mu \mathrm{m})$ semi-preparative column $\left.{ }^{5}, 10\right)$ resulted in a loss of resolution of the $\mathrm{C}_{1}$ and $\mathrm{C}_{2}$ components. This very difficult separation problem was overcome by use of a shallow gradient of acetonitrile on a large column of small-particle reversedphase packing (Fig. 2). At higher loadings, this system effectively differentiated $\mathrm{C}_{1}$ and $\mathrm{C}_{2}$ despite the subtle nature of their structural difference (vide infra), allowing 30 50 $\mathrm{mg}$ of each to be obtained in pure form per chromatographic run after desalting. Quantities of pure $A, B_{1}$ and $B_{2}(6 \sim 20 \mathrm{mg})$ also were obtained per run after desalting.

For isolation of components $\mathrm{C}_{3}$ and $\mathrm{C}_{4}$ the IRA-68 step was omitted and the affinity chromatography was conducted with only brief exposure to dilute ammonia. Semi-preparative RPHPLC on a small-particle column (Whatman Partisil ODS-3, $2.2 \times 50 \mathrm{~cm}, 10 \mu \mathrm{m}$ ) using a stepgradient of acetonitrile in potassium phosphate buffer provided components $\mathrm{C}_{1}, \mathrm{C}_{2}, \mathrm{C}_{3}$ and $\mathrm{C}_{4}$, which eluted at $29 \%$ acetonitrile.

\section{Mass Spectral and Chemical Characterization}

Detailed information on the isolated components (Table 2) was provided by FAB-MS, ${ }^{7}$ ) which revealed from relative intensities of peaks in the molecular ion clusters that two atoms of chlorine were present in each component.

Components $C_{1}$ and $C_{2}$ each had a nominal
Fig. 1. Analytical RPHPLC chromatogram of affinity-purified parvodicin complex before (a) and after (b) treatment with ammonia.

Altex Ultrasphere-ODS, $5 \mu \mathrm{m}, 4.6 \times 150 \mathrm{~mm}$; $30 \sim 35 \%$ acetonitrile in $0.01 \mathrm{M}$ phosphate ( $\mathrm{pH} 3.2)$; $1.5 \mathrm{ml} /$ minute flow rate; UV detection at $220 \mathrm{~nm}$. The relative retention times of vancomycin $(\mathrm{V})$, teicoplanin A2-2 (T) and aridicin A (AA) are noted in (a).

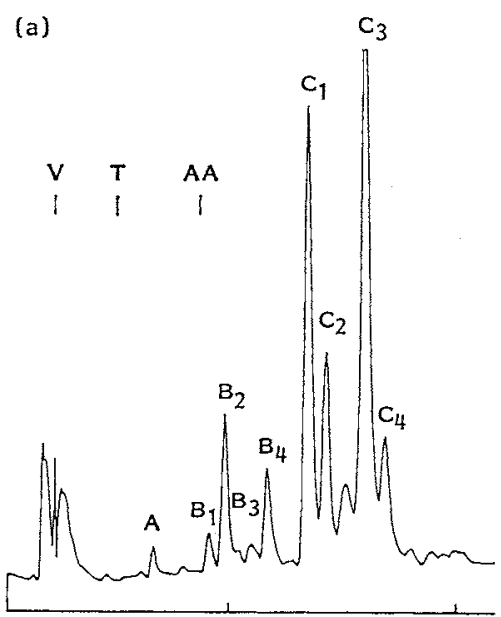

(b)

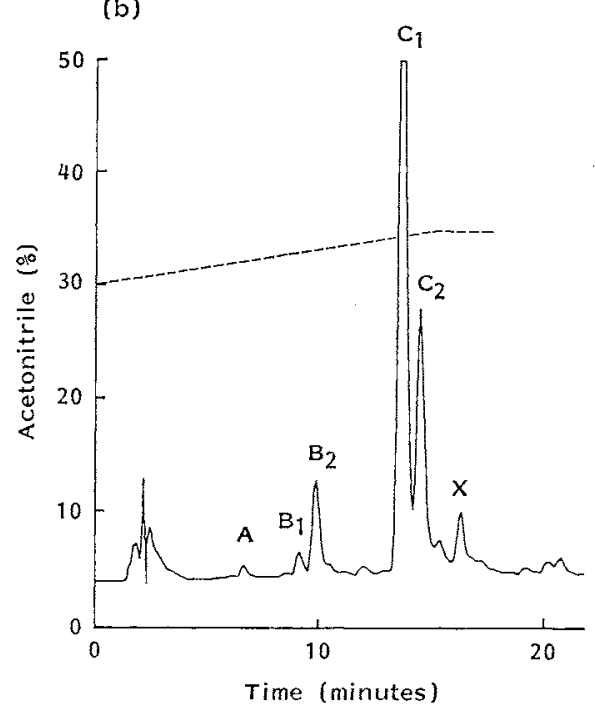

mass of 1,730 daltons. An exact mass measurement of the $\mathrm{MH}^{+}$of $\mathrm{C}_{1}$ was obtained at a resolution of 10,000 by peak matching against the $\mathrm{MH}^{+}(1,758$ daltons $)$ of renin substrate, providing a determined accurate mass of $1,731.496 \pm 0.01$ daltons. Given the constraint of two chlorine atoms in the molecule, the number of possible elemental compositions was narrowed ${ }^{7)}$ and, in conjunction with chemical and additional spectral data (vide infra), a molecular formula of $\mathrm{C}_{83} \mathrm{H}_{88} \mathrm{Cl}_{2} \mathrm{~N}_{8} \mathrm{O}_{28}$ (calculated mass: $\mathrm{m} / \mathrm{z}$ $1,730.503$ ) was established. Major fragment ions in the spectrum of each component indicated the presence of both a hexose $\left(m / z 1,569, \mathrm{MH}^{+}-162\right)$ and an $N$-dodecanoyl hexuronic acid $(\mathrm{m} / z \mathrm{z} 1,374$, 
Fig. 2. Preparative RPHPLC chromatogram of ammonia-treated, affinity-purified parvodicin complex $(650 \mathrm{mg})$.

Vydac $\mathrm{C} 18,15 \sim 20 \mu \mathrm{m}, 300 \mathrm{~A}, 5.1 \times 50 \mathrm{~cm} ; 15 \sim 25 \%$ acetonitrile in $0.01 \mathrm{~m}$ phosphate (pH 6.0 ); $100 \mathrm{ml} / \mathrm{minute}$ flow rate; UV detection at $280 \mathrm{~nm}$.

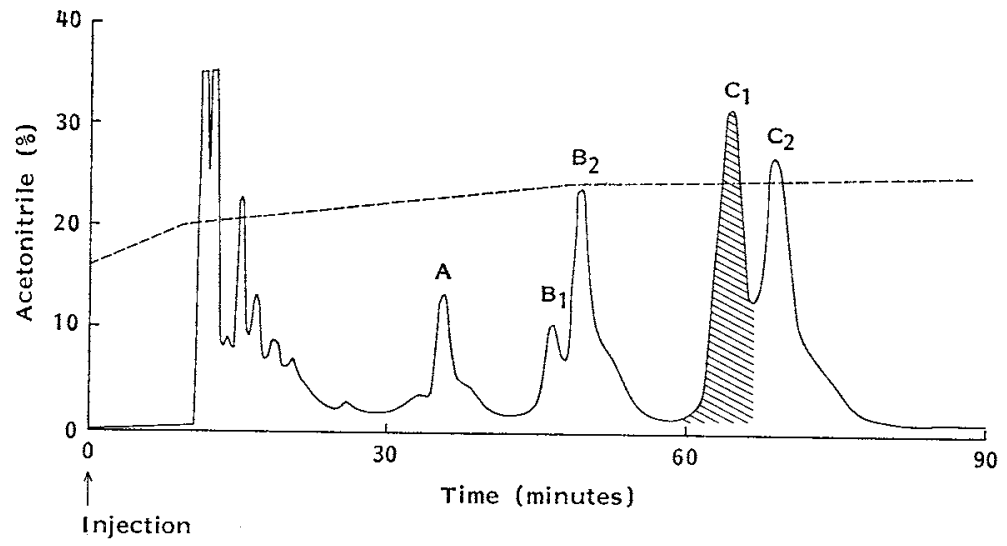

$\mathrm{MH}^{+}$-357) moiety at terminal locations. ${ }^{7)}$ An $N$-dodecanoyl glucuronic acid moiety had been observed previously as a constituent of aridicin C. ${ }^{31}$

The 1,772 dalton nominal mass determined from the FAB-MS of components $C_{3}$ and $C_{4}$ suggested the presence of an additional acetyl group (42 daltons) in these molecules. Fragment ions observed at $m / z 1,416\left(\mathrm{MH}^{+}-357\right)$ indicated that the acetyl function did not reside on the $\mathrm{N}$-dodecanoyl hexuronic acid moiety of these components. Brief ammonolysis collapsed component $\mathrm{C}_{3}$ to $\mathrm{C}_{1}$ and component $\mathrm{C}_{4}$ to $\mathrm{C}_{2}$, each identified by RPHPLC and confirmed by FAB-MS analysis; this base lability of the acetyl group suggested that it was attached at an oxygen rather than a nitrogen atom.

Similarly, FAB-MS analysis revealed a nominal mass of 1,716 daltons for both components $\mathbf{B}_{1}$ and $\mathrm{B}_{2}$, with fragment ions indicating the presence of a hexose $\left(m / z 1,555, \mathrm{MH}^{+}-162\right)$ and an $N$ undecanoyl hexuronic acid $\left(m / z 1,374, \mathrm{MH}^{+}-343\right)$ moiety in each component. FAB-MS analysis of component $\mathbf{A}$ indicated a nominal mass of 1,702 daltons and the presence of a hexose $\left(\mathrm{m} / z \mathrm{z}, 541, \mathrm{MH}^{+}\right.$ $-162)$ and an $N$-decanoyl hexuronic acid $\left(m / z 1,374, \mathrm{MH}^{+}-329\right)$ moiety.

Upon mild acid hydrolysis under two different sets of conditions, each of these components liberated the same aglycone (aglycone $\mathrm{I}, \mathrm{MH}^{+} m / z 1,212$, derived molecular formula $\mathrm{C}_{58} \mathrm{H}_{47} \mathrm{Cl}_{2} \mathrm{~N}_{7} \mathrm{O}_{18}$ ) and hexosyl aglycone $\left(\mathrm{MH}^{+} m / z 1,374\right)$; the hexose was identified by carbohydrate analysis ${ }^{10)}$ as $\mathrm{D}$-mannose. Therefore, with the structural difference between the $A, B$ and $C_{1} / C_{2}$ components and the structural difference within the isomeric pairs $B_{1} / B_{2}, C_{1} / C_{2}$ and $C_{3} / C_{4}$ apparently confined to the glycolipid moiety, fatty acid analysis was conducted. Samples were subjected to total methanolysis and organic extracts of the products were analyzed by GC and GC-MS ${ }^{12,31)}$ (Table 2). Methyl 10-methylundecanoate and methyl n-dodecanoate were identified by comparison with authentic standards as the respective methanolysis products from $C_{1} / C_{3}$ and $C_{2} / C_{4}$. Similarly identified were methyl 9-methyldecanoate from $B_{1}$, methyl $n$-undecanoate from $\mathrm{B}_{2}$ and methyl $n$-decanoate from $\mathrm{A}$.

These data indicate that parvodicins $\mathrm{A} \sim \mathrm{C}$, like aridicins $\mathrm{A} \sim \mathrm{C}$, are based upon a common mannosyl aglycone with individual members differentiated by the nature of the $N$-acyl group in the aminodeoxy hexuronic acid moiety. $8,10,31$ ) Additional variation is introduced into some parvodicin components by a base-labile $O$-acetyl group, a functionality unique among the known glycopeptide 
Table 2. Characterization of parvodicins.

\begin{tabular}{|c|c|c|c|c|c|c|c|c|c|}
\hline \multirow{2}{*}{$\begin{array}{l}\text { Com- } \\
\text { ponent }\end{array}$} & \multirow{2}{*}{$\begin{array}{l}\text { Empirical } \\
\text { formula }\end{array}$} & \multicolumn{3}{|c|}{ FAB-MS $(m / z)$} & \multicolumn{3}{|c|}{ Derived fatty acid methyl ester } & \multicolumn{2}{|c|}{$\mathrm{UV}\left(\mathrm{E}_{\mathrm{icm}}^{1 \%}, 280 \mathrm{~nm}\right)$} \\
\hline & & $\mathrm{MH}^{+}$ & Fragment 1 & Fragment 2 & & $\begin{array}{l}\mathrm{MH}^{+} \\
(m / z)\end{array}$ & $\begin{array}{c}\mathrm{GCRT}^{\mathrm{a}} \\
\text { (minutes) }\end{array}$ & $\begin{array}{c}\mathrm{CH}_{3} \mathrm{CN}- \\
\mathrm{H}_{2} \mathrm{O}(1: 1)\end{array}$ & $\stackrel{(0.1 \mathrm{M}}{\mathrm{HCl})}$ \\
\hline A & $\mathrm{C}_{81} \mathrm{H}_{84} \mathrm{Cl}_{2} \mathrm{~N}_{8} \mathrm{O}_{29}$ & 1,703 & 1,541 & 1,374 & $n$-Decanoate & 187 & $5.26^{\mathrm{b}}$ & 61 & - \\
\hline $\mathrm{B}_{1}$ & $\mathrm{C}_{82} \mathrm{H}_{86} \mathrm{Cl}_{2} \mathrm{~N}_{8} \mathrm{O}_{2 \vartheta}$ & 1,717 & 1,555 & 1,374 & 9-Methyl decanoate & 201 & $6.10^{\mathrm{b}}$ & 60 & - \\
\hline $\mathbf{B}_{2}$ & $\mathrm{C}_{82} \mathrm{H}_{88} \mathrm{Cl}_{2} \mathrm{~N}_{8} \mathrm{O}_{2 \theta}$ & 1,717 & 1,555 & 1,374 & $n$-Undecanoate & 201 & $6.56^{\mathrm{b}}$ & 57 & - \\
\hline $\mathrm{C}_{1}$ & $\mathrm{C}_{83} \mathrm{H}_{83} \mathrm{Cl}_{2} \mathrm{~N}_{8} \mathrm{O}_{28}$ & 1,731 & 1,569 & 1,374 & 10-Methyl undecanoate & 215 & $6.90^{\circ}$ & 58 & 51 \\
\hline $\mathrm{C}_{2}$ & $\mathrm{C}_{83} \mathrm{H}_{88} \mathrm{Cl}_{2} \mathrm{~N}_{8} \mathrm{O}_{29}$ & 1,731 & 1,569 & 1,374 & $n$-Dodecanoate & 215 & $7.34^{\mathrm{e}}$ & - & 45 \\
\hline $\mathrm{C}_{3}$ & $\mathrm{C}_{85} \mathrm{H}_{80} \mathrm{Cl}_{2} \mathrm{~N}_{8} \mathrm{O}_{30}$ & 1,773 & - & 1,416 & 10-Methyl undecanoate & 215 & $6.90^{\mathrm{c}}$ & - & 46 \\
\hline $\mathrm{C}_{4}$ & $\mathrm{C}_{85} \mathrm{H}_{90} \mathrm{Cl}_{2} \mathrm{~N}_{8} \mathrm{O}_{30}$ & 1,773 & - & 1,416 & $n$-Dodecanoate & 215 & $7.34^{\mathrm{c}}$ & - & 45 \\
\hline
\end{tabular}

a $\mathrm{GC}$ retention times. ${ }^{\text {b }} 90 \sim 275^{\circ} \mathrm{C}, 10^{\circ} \mathrm{C} /$ minute. $75 \sim 250^{\circ} \mathrm{C}, 12^{\circ} \mathrm{C} /$ minute. 
antibiotics of this class. ${ }^{40}$ Within the heptapeptide core of the parvodicin aglycone, mass spectral data indicate the absence of one oxygen and two chlorine atoms relative to aridicin aglycone ${ }^{8)}$ and the presence of one additional methylene unit relative to teicoplanin aglycone. ${ }^{41)}$

\section{Structure of the Parvodicins}

The structure of the parvodicin aglycone, as well as the form and sites of carbohydrate and acetyl group attachment in parvodicins $C_{1}$ and $C_{3}$, was derived from comparison of the 2D NMR spectral patterns from $C_{1}$ and $C_{3}$ with those from aridicin $A^{82}$ and teicoplanin A2-2.22 The spectral analysis was facilitated by the high resolution observed for individual resonances in spectra recorded at 500 $\mathrm{MHz}$ in $\mathrm{D}_{2} \mathrm{O}-\mathrm{DMSO}-d_{6}(1: 1)$ solvent mixtures at $45 \sim 50^{\circ} \mathrm{C}$ and $\mathrm{pH} 6$. Under these conditions, signals for the amine, amide, carboxyl and hydroxyl protons are not observed due to exchange with the $\mathrm{D}_{2} \mathrm{O}$ cosolvent.

Immediately apparent at highest field in the unenhanced one-dimensional spectrum of parvodicin $\mathrm{C}_{1}$ (Fig. 3) are the six-proton methyl doublet,* the methine and the eight methylene proton signals expected for the 10-methyl undecanoyl portion of the glycolipid residue. Also, an $N$-methyl singlet (2.34 $\mathrm{ppm}$ ) is obvious. The remaining signal assignments (Table 3 ) are derived from 2D proton correlation spectroscopy (COSY) and nuclear Overhauser spectroscopy (NOESY) experiments, ${ }^{8)}$ which provide information on the bond connectivities and short, through-space relationships among individual protons. These data are summarized in Table 4, with the following spectral highlights instrumental in the elucidation of parvodicin $\mathrm{C}_{1}$.

The 2D delayed-COSY spectrum of parvodicin $\mathrm{C}_{1}$ revealed crosspeaks representative of protonproton coupling connectivities for seven aromatic spin systems. The crosspeak patterns observed for the rings designated $B, D, E, F$ and $G^{43)}$ were identical to those in the corresponding spectra of aridicin $\mathrm{A}$ recorded under similar conditions, suggesting a structural homogeneity in these portions of the two molecules. The $2 \mathrm{D}$ NOE spectral patterns observed for the $\mathrm{B}, \mathrm{D}, \mathrm{E}$ and $\mathrm{F}$ rings of the two molecules also were extremely similar, as was the set of strong crosspeaks among the resonances A2, $\mathrm{E} 2, \mathrm{~A} 1^{\prime}, \mathrm{B} 6, \mathrm{E} 1^{\prime}$ and $\mathrm{A} 2^{\prime}$. This pattern is a common feature in the $2 \mathrm{D}$ NOE spectrum of all biologically active glycopeptide antibiotics of this class analyzed to date ${ }^{8,42,44,45)}$ and is a direct consequence of the stereochemical features within the $\mathrm{A} \sim \mathrm{E}$ framework required for binding of these molecules to the L-Lys-D-Ala-D-Ala terminus of the cell wall peptidoglycan chain.4,46,47) Within ring A, the appearance of the A2 resonance as a doublet $\left(\delta 7.56, J_{\triangle 2, A B}=2.0 \mathrm{~Hz}\right)$, as in the spectra of both aridicin A and teicoplanin A2-2, indicated the presence of a chlorine atom at A3. The resonance at $\delta 7.21\left(\mathrm{~d}, J_{\Delta 5, \mathrm{~A} 6}\right.$ $=8.3 \mathrm{~Hz}$ ) was assigned as A5 on the basis of the NOE observed to A6, despite the absence of an A5/A6 COSY crosspeak. Under the conditions of this particular delayed-COSY experiment (optimized for $2 \mathrm{~Hz}$ couplings), the weak crosspeak expected for these ortho-paired spins was absent because of excessive line-broadening in the A5 and A6 resonances. ${ }^{42)}$ The ABMX coupling pattern, with each resonance appearing as a doublet of doublets, observed for ring $\mathrm{C}$ in the $2 \mathrm{D}$ COSY spectrum of parvodicin $\mathrm{C}_{1}$ revealed the absence of chlorine on this ring. This was strengthened by the presence of a strong $\mathrm{C} 3 /$ B2 NOE signal which was not observed in the spectrum of either aridicin A or teicoplanin A2-2. The strong NOE crosspeak pattern involving $\mathrm{C} 6, \mathrm{C} 2, \mathrm{C} 2^{\prime}, \mathrm{C}^{\prime} \mathrm{a}$ and $\mathrm{C} 1^{\prime} \mathrm{b}$, as in the teicoplanin spectrum, indicated the absence of $\mathrm{a} \mathrm{Cl}^{\prime}$ hydroxyl function in parvodicin $\mathrm{C}_{1}$.

* As a consequence of the y-axis expansion used for ease of visualization of the one-proton resonances in Fig. 3, sidebands bracketing this doublet are magnified, giving it the appearance of a multiplet. 
Fig. 3. One-dimensional ${ }^{1} \mathrm{H}$ NMR spectrum of parvodicin $\mathrm{C}_{1}$ at $500 \mathrm{MHz}$ in $\mathrm{D}_{2} \mathrm{O}-\mathrm{DMSO}-d_{6}(1: 1)$ at $45^{\circ} \mathrm{C}$.

Irr $\mathrm{H}_{2} \mathrm{O}$ : Residual signal from water suppression.

(a)
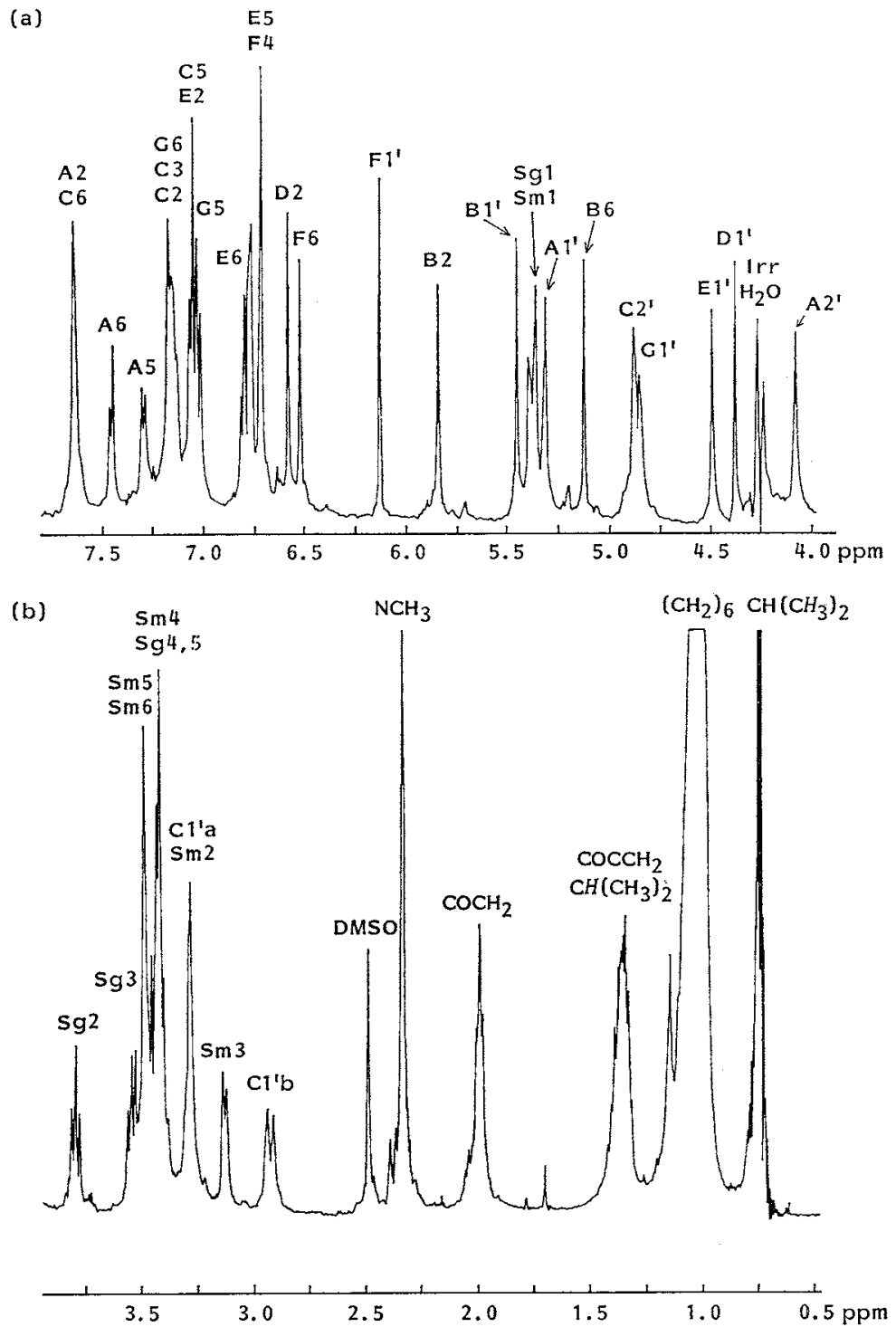

The absence of F2/F4 and F2/F6 COSY crosspeaks and F2/F1' NOE allowed placement of the second chlorine at F2, as in the aridicins. The F3 hydroxyl was inferred from the appearance of the F4 resonance as a doublet $(6.68 \mathrm{ppm}, 3.0 \mathrm{~Hz})$ coupled to $F 6$. The strong F6/G2 NOE confirmed the F5-G3 ether linkage. Finally, the strong NOEs observed between the methyl resonance and G1' and G6 allowed placement of the methyl group on the terminal nitrogen atom of the nucleus.

In spite of the absence of crosspeaks to the $\mathrm{NH}$ protons in the $\mathrm{D}_{2} \mathrm{O}-\mathrm{DMSO}-d_{\mathrm{b}}$ solvent mixture, the large number of correlations which existed in the 2D NOE maps suggested that the stereochemistries at the eight chiral centers and six peptide bonds of parvodicin $C_{1}$ were the same as those in aridicin $A$ and teicoplanin A2-2. Furthermore, it was apparent that all three glycopeptides maintained the 
Table 3. Proton chemical shift assignments of parvocidin $\mathrm{C}_{1}{ }^{\mathrm{a}}$

\begin{tabular}{|c|c|c|c|c|c|}
\hline Assignment & $\delta$ & $J(\mathrm{~Hz})$ & Assignment & $\delta$ & $J(\mathrm{~Hz})$ \\
\hline A Residue & & & F Residue & & \\
\hline A2 & 7.56 & $\mathrm{~d}, 2.0$ & F4 & 6.68 & d, 3.0 \\
\hline A5 & 7.21 & $\mathrm{~d}, 8.3$ & F6 & 6.44 & $\mathrm{~d}, 3.0$ \\
\hline A6 & 7.37 & $\mathrm{dd}, 2.0$ and 8.3 & $\mathrm{~F} 1^{\prime}$ & 6.05 & $\mathrm{~s}$ \\
\hline$A 1^{\prime}$ & 5.23 & br & G Residue & & \\
\hline $\mathrm{A} 2^{\prime}$ & 4.00 & $\mathrm{~d}, 2.3$ & G2 & 6.63 & d, 2.3 \\
\hline B Residue & & & G5 & 6.94 & $\mathrm{~d}, 8.2$ \\
\hline B2 & 5.76 & $\mathrm{~d}, 2.3$ & G6 & 7.09 & $\mathrm{dd}, 2.3$ and 8.2 \\
\hline B6 & 5.04 & $\mathrm{~d}, 2.3$ & G1' & 4.77 & br s \\
\hline $\mathrm{B} 1^{\prime}$ & 5.37 & $\mathrm{~s}$ & $\mathrm{NCH}_{3}$ & 2.34 & s \\
\hline C Residue & & & Glycolipid ( $\mathrm{Sg}$ & esidue & \\
\hline $\mathrm{C} 2$ & 7.05 & $\mathrm{dd}, 2.0$ and 8.2 & Sg1 & 5.31 & $\mathrm{~d}, 8.2$ \\
\hline $\mathrm{C} 3$ & 7.08 & $\mathrm{dd}, 2.0$ and 8.2 & $\mathrm{Sg} 2$ & 3.80 & $\mathrm{dd}, 8.2$ and 10 \\
\hline $\mathrm{C} 5$ & 6.98 & dd, 2.0 and 8.5 & $\mathrm{Sg} 3$ & 3.55 & $\mathrm{dd}, 8.0$ and 10 \\
\hline $\mathrm{C} 6$ & 7.56 & dd, 2.0 and 8.5 & $\mathrm{Sg} 4$ & 3.42 & Unresolved \\
\hline $\mathrm{C} 1^{\prime} \mathrm{a}$ & 3.28 & br d & $\mathrm{Sg} 5$ & 3.45 & Unresolved \\
\hline $\mathrm{C} 1^{\prime} \mathrm{b}$ & 2.93 & br d, 13 & $\mathrm{COCH}_{2}$ & 1.99 & $\mathrm{t}, 7.5$ \\
\hline $\mathrm{C} 2^{\prime}$ & 4.80 & $\mathrm{dd}, 3.5$ and 5.0 & $\mathrm{COCCH}_{2}$ & 1.37 & $\mathrm{~m}$ \\
\hline D Residue & & & $\left(\mathrm{CH}_{2}\right)_{6}$ & 1.04 & $\mathrm{~m}$ \\
\hline D4 & 6.63 & $\mathrm{~d}, 2.2$ & $\mathrm{CH}\left(\mathrm{CH}_{3}\right)_{2}$ & 1.37 & $\mathrm{~m}$ \\
\hline $\mathrm{D} 2$ & 6.50 & d, 2.2 & $\mathrm{CH}\left(\mathrm{CH}_{3}\right)_{2}$ & 0.75 & $\mathrm{~d}, 6.5$ \\
\hline $\mathrm{D} 1^{\prime}$ & 4.30 & s & Mannose (Sm) & sidue & \\
\hline E Residue & & & Sm1 & 5.28 & $\mathrm{~d}, 1.8$ \\
\hline $\mathrm{E} 2$ & 6.97 & $\mathrm{~d}, 2.5$ & $\operatorname{Sm} 2$ & 3.28 & dd, 1.8 and 3.5 \\
\hline E5 & 6.68 & $\mathrm{~d}, 8.5$ & $\operatorname{Sm} 3$ & 3.13 & $\mathrm{dd}, 3.5$ and 9.0 \\
\hline E6 & 6.72 & $\mathrm{~d}, 2.5$ and 8.5 & Sm4 & 3.45 & Unresolved \\
\hline $\mathrm{E} 1^{\prime}$ & 4.41 & s & Sm5,6 & 3.49 & Unresolved \\
\hline
\end{tabular}

a Assignments in solvent $\mathrm{D}_{2} \mathrm{O}-\mathrm{DMSO}-d_{8}(1: 1)$ at $45^{\circ} \mathrm{C}$ and $\mathrm{pH}$. Coupling constants are derived from first-order analysis of spin systems.

same three-dimensional solution conformation in this solvent mixture.

Definitive evidence for the placement of mannose at the D5 phenol of parvodicin $C_{1}$ was the COSY crosspeak between the protons at D4 and mannose C-1 (Sm1) indicative of long-range coupling through the glycosidic oxygen atom. This was supported by the strong NOEs $\mathrm{D} 4 / \mathrm{Sm} 1$ and D4/Sm2. The small Sm1-Sm2 coupling constant $(1.8 \mathrm{~Hz})$, as well as the strong NOE pattern $\mathrm{Sm} 1 / \mathrm{Sm} 2, \mathrm{Sm} 2 / \mathrm{Sm} 3$ and $\mathrm{Sm} 3 / \mathrm{Sm} 4$, established the $\alpha$-anomeric linkage of the sugar. ${ }^{8,42)}$ The $J_{3,4}$ coupling of $9 \mathrm{~Hz}$ expected for the ${ }^{4} \mathrm{C}_{1}$ pyranoside form of the D-mannose ring was observed. ${ }^{8,48,49)}$

Finally, the weak NOE crosspeak observed from the anomeric proton glycolipid C-1 (Sg1) to proton $\mathrm{C} 5$ in the $\mathrm{Sg} 1$ cross section of the $2 \mathrm{D}$ NOE spectrum of parvodicin $\mathrm{C}_{1}$ established attachment of the glycolipid at the B4 phenolic oxygen. The appearance of this resonance as a doublet $\left(J_{1,2}=\right.$ $8.1 \mathrm{~Hz}$ ) coupled to $\mathrm{Sg} 2$ was indicative of attachment via a $\beta$-anomeric linkage. The strong syn-axial NOE pattern $\mathrm{Sg} 1 / \mathrm{Sg} 3, \mathrm{Sg} 1 / \mathrm{Sg} 5, \mathrm{Sg} 3 / \mathrm{Sg} 5$ and $\mathrm{Sg} 2 / \mathrm{Sg} 4$, along with the 8 to $10 \mathrm{~Hz}{ }^{3} J$ coupling constants, supported the ${ }^{4} \mathrm{C}^{1}$ conformation of a $\beta$-D sugar. ${ }^{48,48)}$ The extreme similarity of the sugar resonances in the parvodicin $C_{1}$ spectra to those in aridicin $A$ spectra supported assignment of the 2-[10-methylundecanamido]-2-deoxy- $\beta$-D-glucopyranosiduronic acid structure. ${ }^{8,31}$

The one-dimensional and 2D COSY spectra of parvodicin $C_{3}$ were virtually identical to the corresponding spectra of component $C_{1}$ with four exceptions. The first of these was the $0.26 \mathrm{ppm}$ relative 
Table 4. Scalar and 2D NOE connectivities of parvodicin $\mathrm{C}_{1}$.

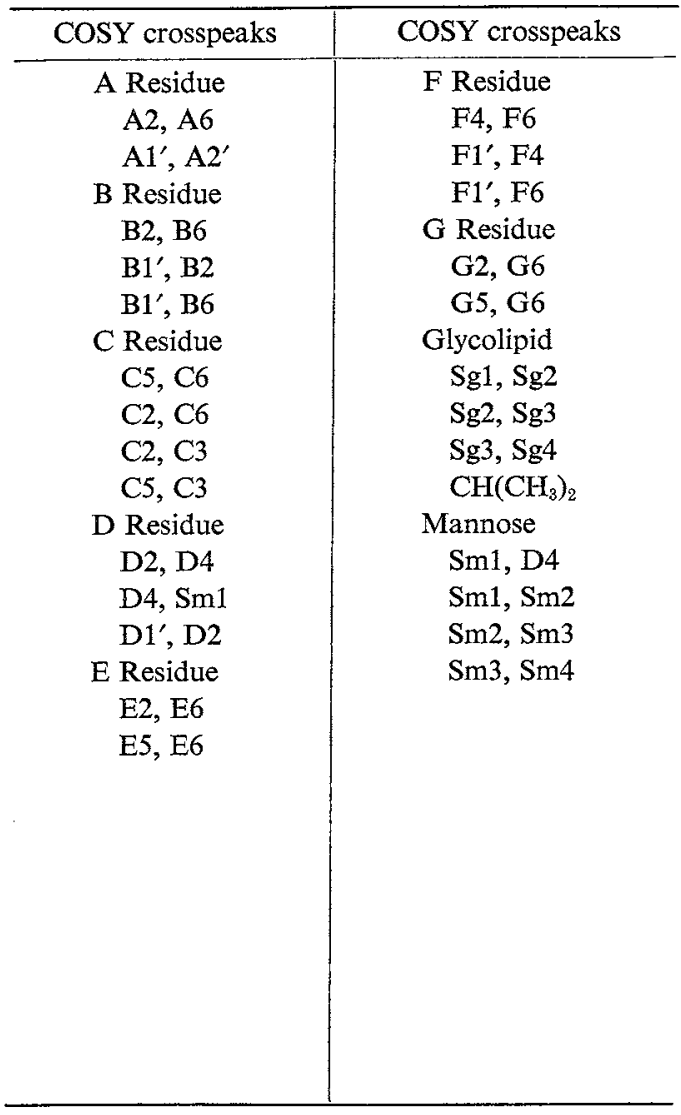

\begin{tabular}{|c|c|}
\hline NOESY crosspeaks & NOESY crosspeaks \\
\hline A Residue & D Residue \\
\hline $\mathrm{A} 2^{\prime}, \mathrm{A} 2$ & $\mathrm{D} 1^{\prime}, \mathrm{D} 2$ \\
\hline $\mathrm{A} 2^{\prime}, \mathrm{E} 2$ & $\mathrm{D} 4, \mathrm{Sm} 1$ \\
\hline $\mathrm{A} 2^{\prime}, \mathrm{A} 1^{\prime}$ & $\mathrm{D} 4, \mathrm{Sm} 2$ \\
\hline $\mathrm{A} 2^{\prime}, \mathrm{E} 1^{\prime}$ & E Residue \\
\hline $\mathrm{A} 1^{\prime}, \mathrm{A} 2$ & E1', E2 \\
\hline $\mathrm{A} 1^{\prime}, \mathrm{E} 1^{\prime}$ & F Residue \\
\hline $\mathrm{A} 1^{\prime}, \mathrm{E} 2$ & F6, G2 \\
\hline $\mathrm{A} 5, \mathrm{~A} 6$ & G Residue \\
\hline $\mathrm{A} 5, \mathrm{~B} 6$ & G1', G6 \\
\hline $\mathrm{A} 2^{\prime}, \mathrm{B} 6$ & $\mathrm{G}^{\prime}, \mathrm{NCH}_{3}$ \\
\hline $\mathrm{A} 2, \mathrm{E} 1^{\prime}$ & G5, G6 \\
\hline B Residue & $\mathrm{G} 6, \mathrm{NCH}_{3}$ \\
\hline B1', B2 & Glycolipid \\
\hline $\mathrm{B1} 1^{\prime}, \mathrm{B} 6$ & $\mathrm{Sg} 1, \mathrm{Sg} 2$ \\
\hline B2, C2 & Sg1, Sg3 \\
\hline $\mathrm{B} 2, \mathrm{C} 3$ & Sg1, Sg5 \\
\hline $\mathrm{B} 6, \mathrm{E} 6$ & $\mathrm{Sg} 2, \mathrm{Sg} 3$ \\
\hline $\mathrm{B} 6, \mathrm{E} 1^{\prime}$ & $\mathrm{Sg} 2, \mathrm{Sg} 4$ \\
\hline $\mathrm{B} 2, \mathrm{~F} 1^{\prime}$ & $\mathrm{Sg} 3, \mathrm{Sg} 5$ \\
\hline C Residue & Mannose \\
\hline $\mathrm{C} 2^{\prime}, \mathrm{C} 1^{\prime} \mathrm{a}$ & Sm1, D4 \\
\hline $\mathrm{C} 2^{\prime}, \mathrm{Cl}^{\prime} \mathrm{b}$ & $\mathrm{Sm} 1, \mathrm{Sm} 2$ \\
\hline $\mathrm{Cl}^{\prime} \mathrm{a}, \mathrm{C1^{ \prime }} \mathrm{b}$ & $\mathrm{Sm} 2, \mathrm{Sm} 3$ \\
\hline $\mathrm{C} 2, \mathrm{C} 1^{\prime} \mathrm{a}$ & $\mathrm{Sm} 3, \mathrm{Sm} 4$ and 5 \\
\hline $\mathrm{C} 2, \mathrm{Cl}^{\prime} \mathrm{b}$ & \\
\hline $\mathrm{C} 6, \mathrm{C} 1^{\prime} \mathrm{b}$ & \\
\hline C6, C5 & \\
\hline
\end{tabular}

downfield shift (to $5.03 \mathrm{ppm}$ ) of the $\mathrm{G}^{\prime}$ ' resonance of parvodicin $\mathrm{C}_{3}$. This resonance, adjacent to the amine terminus of the peptide chain, is strongly affected by changes in the charge density at the nitrogen atom, which varies with sample $\mathrm{pH}^{83}$ The observed chemical shift differences between these resonances, therefore, can be attributed simply to a slight $\mathrm{pH}$ difference between the two samples rather than to a structural difference in this region of the two molecules.

The three remaining differences are structurally significant. An additional three-proton singlet $(1.90 \mathrm{ppm})$, consistent with the presence of an $O$-acetyl function, is observed in the spectrum of component $\mathrm{C}_{3}$. Also, the resonances for the two protons of the mannose $\mathrm{C}-6$ (Sm6, $4.08 \mathrm{ppm}$ ) and the proton of the mannose C-5 (Sm5, $3.66 \mathrm{ppm})$ are shifted downfield by 0.59 and $0.17 \mathrm{ppm}$ from their respective positions in the spectrum of component $C_{1}$. These differences are consistent with the presence of the $O$-acetyl function at the $\mathrm{C}-6$ oxygen of the mannose residue, ${ }^{50)}$ with the remainder of the molecule identical in structure to component $\mathrm{C}_{1}$.

NMR spectral analysis of the remaining parvodicin components was not conducted. However, since mass spectral data and hydrolysis experiments indicated that components $A, B_{1}, B_{2}, C_{1}, C_{2}, C_{3}$ and $\mathrm{C}_{4}$ are based on a common mannosyl aglycone, it is inferred, by analogy to the aridicin, ${ }^{8,10,31)}$ kibdelin ${ }^{12)}$ and teicoplanin ${ }^{41,51)}$ series of glycopeptides, that the $N$-acylglucuronic acid moiety of each component is attached at the B-4 phenol. Component $\mathrm{C}_{4}$, converted to component $\mathrm{C}_{2}$ under basic conditions, is assumed to be acetylated at the mannose C- 6 oxygen by analogy to component $\mathrm{C}_{3}$. On 
Fig. 4. Structure of the parvodicins.

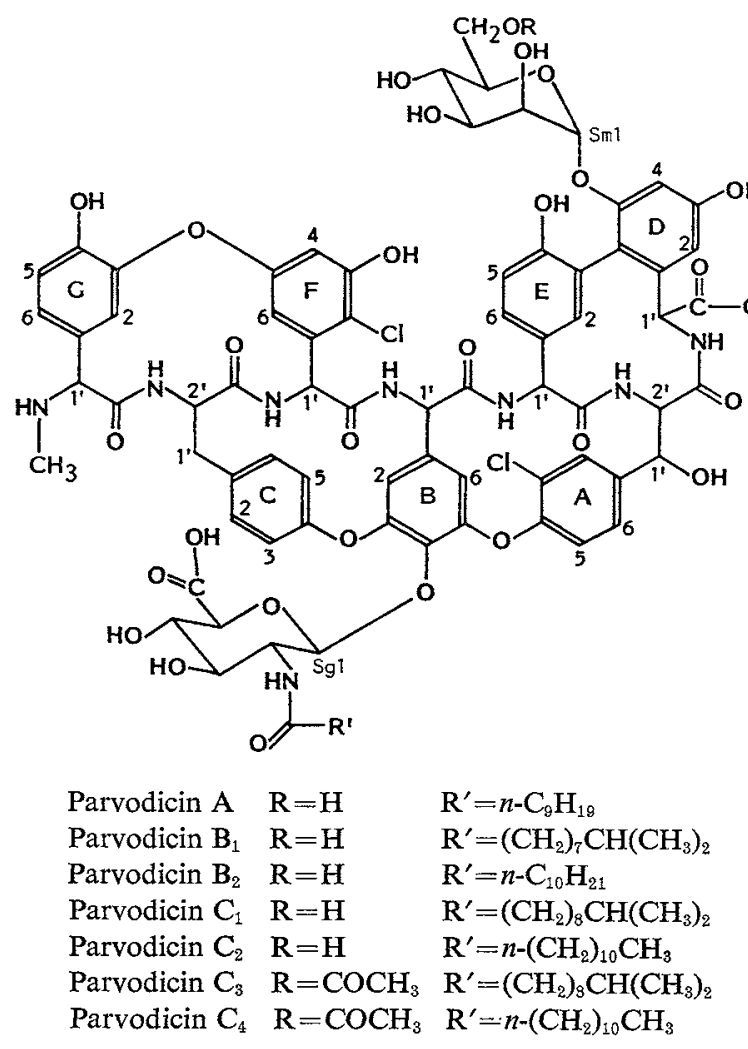

the basis of the data and these assumptions, therefore, the major components of the parvodicin complex are assigned the structures of Fig. 4.

\section{Minor Components of the Complex}

From the analytical chromatogram of Fig. 1a, it is apparent that several minor components also are present in the complex. None of these components were isolated or characterized. However, the components labeled $\mathrm{B}_{3}$ and $\mathrm{B}_{4}$ (Fig. 1a) are, almost certainly, the $O$-acetylated analogues of components $B_{1}$ and $B_{2}$, respectively, based upon their conversion to these components under basic conditions ( $c f$ Fig. 1b).

The species labeled $\mathrm{X}$ in Fig. 1b, also never isolated, is representative of a third structural variation within the complex. Component $\mathrm{X}$ had an analytical RPHPLC retention time similar or identical to that of component $\mathrm{C}_{3}$, with which it co-eluted at the semi-preparative level. FAB-MS of component $\mathrm{C}_{3}$ revealed a minor molecular ion peak cluster at $m / z 1,745$. This cluster remained unchanged in the mass spectra of samples in which $C_{3}$ had been converted entirely to $C_{1}$ by saponification of the acetate ester. While the 14 dalton mass increase of $\mathrm{X}$ relative to $\mathrm{C}_{1} / \mathrm{C}_{2}$ initially was suggestive of a homolog differing in the glycolipid, a minor mass spectral fragment ion cluster at $m / z 1,388$ indicated that the source of heterogeneity resided in the mannosyl aglycone.

This was confirmed with the isolation of a second aglycone (aglycone II) from the acid hydrolysate of a sample of complex enriched in minor components. Aglycone II, slightly more lipophilic than aglycone I, was determined by FAB-MS to be a two-chlorine-containing species of nominal mass 1,225 
Table 5. Proton chemical shift assignments of aglycones. ${ }^{2}$

\begin{tabular}{|c|c|c|c|c|}
\hline \multirow{2}{*}{ Assignment } & \multicolumn{2}{|c|}{ Aglycone I } & \multicolumn{2}{|c|}{ Aglycone II } \\
\hline & $\delta$ & $J(\mathrm{~Hz})$ & $\delta$ & $J(\mathrm{~Hz})$ \\
\hline ANH & 6.71 & 12.2 & 6.72 & 11.7 \\
\hline $\mathrm{A} 1^{\prime}$ & 5.17 & & 5.17 & \\
\hline $\mathrm{A} 2^{\prime}$ & 4.18 & & 4.18 & \\
\hline $\mathrm{A} 2$ & 7.84 & & 7.84 & \\
\hline A6 6 & 7.51 & & 7.52 & \\
\hline A5 & 7.28 & & 7.29 & \\
\hline $\mathrm{BNH}$ & 7.18 & 7.2 & 7.17 & 7.5 \\
\hline $\mathrm{B}^{\prime}$ & 5.63 & & 5.64 & \\
\hline $\mathrm{B} 2$ & 5.83 & & 5.84 & \\
\hline B6 & 5.13 & & 5.13 & \\
\hline $\mathrm{CNH}$ & 8.06 & 8.4 & 8.26 & 8.1 \\
\hline $\mathrm{C} 2^{\prime}$ & 5.01 & & 4.96 & \\
\hline $\mathrm{C} 1^{\prime} \mathrm{a}$ & 3.41 & 14.4 and 5.7 & 3.41 & 14.4 and 6.0 \\
\hline $\mathrm{C} 1^{\prime} \mathrm{b}$ & 2.97 & 14.4 and 2.7 & 3.03 & \\
\hline $\mathrm{C} 2$ & 7.17 & & 7.17 & \\
\hline $\mathrm{C} 3$ & 7.25 & & 7.23 & \\
\hline $\mathrm{C} 5$ & 7.09 & & 7.09 & \\
\hline C6 & 7.78 & & 7.77 & \\
\hline DNH & 8.48 & 6.3 & 8.48 & 6.8 \\
\hline $\mathrm{D} 1^{\prime}$ & 4.51 & & 4.51 & \\
\hline D2 & 6.34 & & 6.36 & \\
\hline D4 & 6.47 & & 6.47 & \\
\hline ENH & 8.50 & 6.0 & 8.50 & 6.8 \\
\hline$E 1^{\prime}$ & 4.41 & & 4.43 & \\
\hline $\mathrm{E} 2$ & 7.16 & & 7.17 & \\
\hline E5 & 6.74 & & 6.74 & \\
\hline $\mathrm{E} 6$ & 6.78 & & 6.78 & \\
\hline FNH & 7.63 & 10.6 & 7.60 & 10.2 \\
\hline $\mathrm{F} 1^{\prime}$ & 6.13 & & 6.15 & \\
\hline $\mathrm{F} 4$ & 6.68 & & 6.68 & \\
\hline F6 & 6.58 & & 6.57 & \\
\hline $\mathrm{G} 1^{\prime}$ & 5.39 & & 5.50 & \\
\hline G2 & 6.84 & & 6.99 & \\
\hline G5 & 7.09 & & 7.11 & \\
\hline G6 & 7.26 & & 7.28 & \\
\hline N-Methyl 1 & 2.56 & & 2.68 & \\
\hline N-Methyl 2 & - & & 2.89 & \\
\hline
\end{tabular}

a Assignments in DMSO- $d_{6}$ containing $3 \%$ triffuoroacetic acid at $40^{\circ} \mathrm{C}$.

daltons, 14 daltons higher in mass than aglycone $\mathrm{I}$.

One-dimensional ${ }^{1} \mathrm{H}$ NMR spectra were recorded at $500 \mathrm{MHz}$ in $\mathrm{D}_{2} \mathrm{O}-\mathrm{DMSO}-d_{6}(1: 1)$ at $\mathrm{pH}$ $6 \sim 7$ and $40^{\circ} \mathrm{C}$ for both species. Resonances in the spectrum of aglycone I displayed chemical shifts and couplings which were virtually identical to those observed for the protons of the heptapeptide core in the spectrum of component $\mathrm{C}_{1}$ and were assigned on this basis. Exceptions were the resonances for $\mathrm{Gl}^{\prime}$, shifted $0.23 \mathrm{ppm}$ upfield from its position in the spectrum of component $\mathrm{C}_{1}$, presumably because of sample $\mathrm{pH}$ differences (vide supra), and the resonances for $\mathrm{D} 2$ and $\mathrm{D} 4$, which were shifted upfield 0.21 and $0.28 \mathrm{ppm}$, respectively, as is expected when mannose is removed., ${ }^{8,52)}$ In the spectrum of aglycone II, the additional methylene/methyl resonance expected on the basis of the mass spectral 
Table 6. Antibacterial activity of the parvodicins.

\begin{tabular}{|c|c|c|c|c|c|c|c|c|c|}
\hline \multirow[b]{2}{*}{ Compound } & \multicolumn{9}{|c|}{$\operatorname{MIC}(\mu \mathrm{g} / \mathrm{ml})$} \\
\hline & $\underset{\text { S.a. }}{\text { SH127 }}$ & $\begin{array}{l}\text { S. } a \text {. } \\
910\end{array}$ & $\underset{209 \mathrm{P}}{S . a .}$ & $\underset{675^{\circ}}{S . a .}$ & $\begin{array}{l}\text { S.e. } \\
2479\end{array}$ & $\begin{array}{l}S . h . \\
651^{a}\end{array}$ & $\begin{array}{c}\text { E.f. } \\
34358^{\mathrm{a}}\end{array}$ & $\begin{array}{r}E . f . \\
657^{\mathrm{a}}\end{array}$ & $\underset{2657}{S . s .}$ \\
\hline Parvodicin complex & 3.1 & 1.6 & 0.8 & 3.1 & 12.5 & 25 & 0.1 & 0.1 & 6.3 \\
\hline Parvodicin $\mathrm{C}_{4}$ & 3.1 & 3.1 & 1.6 & 6.3 & 25 & 25 & 0.4 & 0.4 & 12.5 \\
\hline Parvodicin $\mathrm{C}_{3}$ & 1.6 & 1.6 & 0.4 & 3.1 & 25 & 25 & 0.1 & 0.05 & 6.3 \\
\hline Parvodicin $\mathrm{C}_{2}$ & 0.8 & 0.8 & 0.4 & 1.6 & 12.5 & 50 & 0.4 & 0.2 & 0.8 \\
\hline Parvodicin $C_{1}$ & 0.8 & 0.4 & 0.4 & 0.8 & 6.3 & 25 & 0.2 & 0.2 & 0.4 \\
\hline Aglycone I & 0.4 & 0.4 & 0.4 & 0.8 & 0.8 & 3.1 & 1.6 & 1.6 & 0.8 \\
\hline Aglycone II & 0.4 & 0.4 & 0.4 & 0.4 & 0.8 & 6.3 & 1.6 & 1.6 & 0.8 \\
\hline Aridicin A & 6.3 & 3.1 & 1.6 & 6.3 & 50 & 50 & 1.6 & 0.8 & 25.0 \\
\hline Teicoplanin & 3.1 & 0.8 & 0.4 & 3.1 & 12.5 & 12.5 & 0.1 & 0.1 & 1.6 \\
\hline Vancomycin & 1.6 & 1.6 & 1.6 & 1.6 & 1.6 & 3.1 & 1.6 & 1.6 & 1.6 \\
\hline Parvodicin A & 3.1 & N.T. & N.T. & 6.3 & 12.5 & 50 & 3.1 & 3.1 & N.T. \\
\hline Parvodicin $\mathrm{B}_{1}$ & 1.6 & N.T. & N.T. & 3.1 & 50 & 50 & 1.6 & 3.1 & N.T. \\
\hline Parvodicin $\mathrm{B}_{2}$ & 6.3 & N.T. & N.T. & 6.3 & 50 & 50 & 3.1 & 3.1 & N.T. \\
\hline
\end{tabular}

\& Methicillin-resistant strain.

S.a.: Staphylococcus aureus, S.e.: Staphylococcus epidermidis, S.h.: Staphylococcus hemolyticus, E.f.: Enterococcus faecalis, S.s.: Staphylococcus saprophyticus.

N.T.: Not tested.

data was not observed, but careful integration of the $N$-methyl singlet revealed a relative six-proton intensity, suggesting that two methyl groups were present on the terminal nitrogen atoms of this aglycone.

Proof of this simple structural difference was provided by analysis of one- and two-dimensional NMR data obtained at $40^{\circ} \mathrm{C}$ in DMSO- $d_{6}$ containing $3 \%$ trifluoroacetic acid, conditions which allow the amide proton resonances to be observed. As summarized in Table 5, the chemical shifts and amide couplings displayed by the two species were virtually identical, with only the $\mathrm{CNH}(+0.2 \mathrm{ppm})$, $\mathrm{G} 2(+0.15 \mathrm{ppm})$ and $\mathrm{G}^{\prime}(+0.11 \mathrm{ppm})$ resonances affected by the presence of the second methyl group. Also, upon amine protonation under the acidic conditions of this experiment, the two resonances expected for the diastereotopic $N$-methyl groups were observed. In the 2D NOE spectrum of aglycone II, the observed crosspeak patterns were extremely similar to those in the spectrum of aridicin aglycone recorded under comparable conditions, ${ }^{8}$ providing unambiguous evidence that the stereochemistries at the chiral centers of these two glycopeptides were identical.

\section{Antibacterial Activity}

Comparison of the in vitro activity of the Affigel-purified parvodicin complex ( $c a .85 \% \mathrm{w} / \mathrm{w}$ ) with the isolated components was informative (Table 6). Parvodicins $\mathrm{C}_{1}$ and $\mathrm{C}_{2}$ were found to be considerably more potent than their acetylated analogs $\mathrm{C}_{3}$ and $\mathrm{C}_{4}$ against selected strains of Staphylococci in vitro. This explained the observed increase in the in vitro activity of the complex during the purification process as components $C_{3}$ and $C_{4}$ were saponified to $C_{1}$ and $C_{2}$.

Parvodicin $C_{1}$ is the most active lipid-containing compound isolated by us to date. MIC values against Staphylococcus aureus strains are 1 4-fold lower than those of teicoplanin complex and 2 4fold lower than those of vancomycin in our tests. Activity against coagulase-negative Staphylococci, though better than that of aridicin $A$, is inferior to that of vancomycin. In common with most of the lipid-containing glycopeptides, activity against Enterococci was high. As observed previously ${ }^{53}$ in the 
aridicin series of glycopeptides, the nature and length of the fatty acid portion of the glycolipid moiety are subtle determinants of activity in vitro. Terminal branching of the lipid chain appears to result in improved activity $\left(\mathrm{C}_{3}>\mathrm{C}_{4}, \mathrm{C}_{1}>\mathrm{C}_{2}, \mathrm{~B}_{1}>\mathrm{B}_{2}\right)$. Activity appears to peak at a chain length of twelve carbons $\left(\mathrm{C}_{2}>\mathrm{B}_{2} \simeq \mathrm{A} ; \mathrm{C}_{1}>\mathrm{B}_{1}\right)$. Removal of the sugars leads to a considerable increase in activity against coagulase-negative Staphylococci.

\section{Pharmacokinetics}

Pharmacokinetic studies of parvodicin $\mathrm{C}_{1}$ in mice indicated the potential for a long duration of action. Intravenous administration $(20 \mathrm{mg} / \mathrm{kg})$ resulted in a very high peak serum concentration $(143 \mu \mathrm{g} / \mathrm{ml})$, which declined in a mono-exponential manner with an elimination half-life of 11 hours. This was considerably longer than the $\beta$ elimination half-life determined in parallel studies ${ }^{32)}$ for vancomycin ( 0.33 hour), teicoplanin complex (2.5 hours) and aridicin A (3.7 hours), and was attributed to the low systemic clearance $(0.14 \mathrm{ml} / \mathrm{minute} / \mathrm{kg})$ of the compound. This, in turn, may be the result of the high serum binding $(>98 \%$ ) of the molecule due to its acidity and greater lipophilicity relative to aridicin A. These findings are consistent with the pharmacokinetic structure-activity relationships developed previously ${ }^{32}$ ) for this class of antibiotics.

\section{Conclusions}

Upon thorough investigation of its morphology, chemotaxonomy and physiology, strain SK\&FAAJ-271 was determined to be a new species, which we have designated Actinomadura parvosata. Isolated from fermentations of this organism was a novel complex of acidic, lipophilic antibiotics of the vancomycin-ristocetin class, ${ }^{40)}$ the parvodicins. Mass spectral studies, in conjunction with chemical studies, revealed that parvodicins $\mathrm{A} \sim \mathrm{C}$ were based upon a common mannosyl aglycone.

The structure within the heptapeptide core of this species, as well as the form and sites of carbohydrate attachment, were determined from $2 \mathrm{D}$ NMR studies of parvodicin $\mathrm{C}_{1}$. Similar studies of parvodicin $\mathrm{C}_{3}$ allowed determination of the mannose $\mathrm{C}-6$ oxygen as the site of attachment of the $O$ acetyl group, a functionality unique among the known members of this class of antibiotics. The remaining isolated components differed from $\mathrm{C}_{1}$ or $\mathrm{C}_{3}$ only in the length and/or nature of the acyl portion of the $N$-acyl-aminodeoxyglucuronic acid residue. One or more minor components of the complex which were not isolated are $N$-dimethyl analogs of some major components.

Parvodicin $C_{1}$ is the component most active in vitro against staphylococcal strains. The acidity and lipophilicity of the molecule lead to high serum binding and a long in vivo $\beta$ elimination half-life, suggesting the potential for a long in vivo duration of action.

\section{References}

1) Hashisaki, P. A. \& J. A. Jacobson: Characteristics, control and treatment of methicillin-resistant Staphylococcus aureus infection. Clin. Pharm. 1: $343 \sim 348,1982$

2) KIRBY, W. M. M.: Vancomycin therapy of severe staphylococcal infections. J. Antimicrob. Chemother. 14 (Suppl. D): $73 \sim 78,1984$

3) Rake, J. B.; R. Gerber, R. J. Mehta, D. J. Newman, Y. K. Oh, C. Phelen, M. C. Shearer, R. D. Sitrin \& L. J. NisBeT: Glycopeptide antibiotics: A mechanism-based screen employing a bacterial cell wall receptor mimetic. J. Antibiotics 39: 58 67, 1986

4) Nieto, M. \& H. R. Perkins: Modifications of the acyl-D-alanyl-D-alanine terminus affecting complex formation with vancomycin. Biochem. J. 123: 789 803, 1971

5) Sitrin, R.; P. DePhillips, J. Dingerdissen, K. Erhard \& J. Filan: Preparative liquid chromatography: A strategic approach. LC-GC 4:530 550, 1986

6) Folena-Wasserman, G.; R. D. Sitrin, F. Chapin \& K. M. Snader: Affinity chromatography of glycopeptide antibiotics. J. Chromatogr. 392: $225 \sim 238,1987$

7) Roberts, G. D.; S. A. Carr, S. Rottschaefer \& P. W. JefFs: Structural characterization of glycopeptide 
antibiotics related to vancomycin by fast atom bombardment mass spectrometry. J. Antibiotics 38:713 720,1985

8) Jeffs, P. W.; L. Mueller, C. DeBrosse, S. L. Heald \& R. Fisher: Structure of Aridicin A. An integrated approach employing 2D NMR, energy minimization, and distance constraints. J. Am. Chem. Soc. 108: 3063 3075, 1986

9) Shearer, M. C.; P. Actor, B. A. Bowie, S. F. Grappel, C. H. Nash, D. J. Newman, Y. K. OH, C. H. PAN \& L. J. NisBeT: Aridicins, novel glycopeptide antibiotics. I. Taxonomy, production and biological activity. J. Antibiotics 38: 555 560, 1985

10) Sitrin, R. D.; G. W. Chan, J. Dingerdissen, W. Holl, J. R. E. Hoover, J. R. Valenta, L. Webb \& K. M. SNADER: Aridicins, novel glycopeptide antibiotics. II. Isolation and characterization. J. Antibiotics 38: 561 571, 1985

11) Shearer, M. C.; A. J. Glovenella, S. F. Grappel, R. D. Hedde, R. J. Mehta, Y. K. Oh, C. H. Pan, D. H. PitKin \& L. J. Nisbet: Kibdelins, novel glycopeptide antibiotics. I. Discovery, production, and biological evaluation. J. Antibiotics 39: 1386 1394, 1986

12) Folena-Wasserman, G.; B. L. Poehland, E. W-K. Yeung, D. Staiger, L. B. Killmer, K. Snader, J. J. DINGERDISSEN \& P. W. JEFFs: Kibdelins (AAD-609), novel glycopeptide antibiotics. II. Isolation, purification and structure. J. Antibiotics 39: 1395 1406, 1986

13) A preliminary report of this work has appeared: NisBeT, L. J.; M. C. ShEARER, J. B. RAKE, J. J. Dingerdissen, M. DiPaolo, R. D. Sitrin, H. S. Allaudeen, A. J. Glovenella, S. F. Grappel, S. A. Carr, S. L. Heald, G. D. Roberts, S. B. Christensen \& P. W. JefFs: Discovery comparative antibacterial activity and structure elucidation of AAJ-271, a novel group of glycopeptides. Program and Abstracts of the 26th Intersci. Conf. on Antimicrob. Agents Chemother., No. 226, p. 137, New Orleans, Sept. $28 \sim$ Oct. 1,1986

14) National Bureau of Standards: ISCC-NBS centroid color charts. Supplement to NBS circular 553. Standard sample 2106. Office of Standard Reference Materials, National Bureau of Standards, Washington, DC, 1955

15) Kornerup, A. \& J. H. Wanscher: Methuen Handbook of Colour, third edition. Eyre Methuen, London, 1981

16) Kawato, M. \& R. Shinobu: On Streptomyces herbaricolor nov. sp., Supplement: a simple technique for the microscopical observation. Mem. Osaka Univ. Lib. Arts Educ. 8: $114 \sim 119,1959$

17) Becker, B.; M. P. LeChevalier \& H. A. LeChevalier: Chemical composition of cell-wall preparations from strains of various form-genera of aerobic actinomycetes. Appl. Microbiol. 13: 236 243, 1965

18) Lechevalier, M. P.: Identification of aerobic actinomycetes of clinical importance. J. Lab. Clin. Med. $71: 934 \sim 944,1968$

19) Lechevalier, M. P.; C. DeBievre \& H. A. Lechevalier: Chemotaxonomy of aerobic actinomycetes: phospholipid composition. Biochem. Syst. Ecol. 5: 249 260, 1977

20) Gordon, R. E.: Some criteria for the recognition of Norcardia madurae (Vincent) Blanchard. J. Gen. Microbiol. 45: 355 364, 1966

21) Gordon, R. E.: The taxonomy of soil bacteria. In The Ecology of Soil Bacteria. Eds., T. R. G. GRAY \& D. PARKInson, pp. $293 \sim 321$, Liverpool Univ. Press, Liverpool, 1967

22) Gordon, R. E. \& J. M. MiHM: Identification of Norcardia caviae (Erikson) nov. comb. Ann. N.Y. Acad. Sci. $98: 628 \sim 636,1962$

23) Goodfellow, M.; G. Alderson \& J. LACEY: Numerical taxonomy of Actinomadura and related actinomycetes. J. Gen. Microbiol. 112: $95 \sim 111,1979$

24) Shirling, E. B. \& D. Gottlieb: Methods for characterization of Streptomyces sp. Int. J. Syst. Bacteriol. 16: $313 \sim 340,1966$

25) Kurup, P. V. \& J. A. Schmitt: Numerical taxonomy of Nocardia. Can. J. Microbiol. 19: 1035 1048, 1973

26) Pridham, T. G. \& D. Gottlieb: The utilization of carbon compounds by some Actinomycetales as an aid for species determination. J. Bacteriol. 56: 107 114, 1948

27) Nonomura, H. \& Y. Ohara: Distribution of actinomycetes in the soil IX: New species of the genera Microbispora and Microtetraspora and methods for their isolation. J. Ferment. Technol. 49: 887 894, 1971

28) Pan, C. H.; G. Chan, L. J. Nisbet, M. J. Polansky, S. Vogt-Speth \& R. D. Sitrin: Analytical HPLC of the aridicin glycopeptide complex and its application to fermentation development. J. Indust. Microbiol. $1: 303 \sim 310,1987$

29) Folena-Wasserman, G.; B. L. Poehland, L. B. Killmer, E. W-K. Yeung, P. W. Jeffs, J. J. Dingerdissen, 
M. C. Shearer, S. F. Grappel, C. H. Pan \& L. J. Nisbet: Affinity isolation and characterization of new glycopeptide antibiotics from SK\&F AAD-609. Program and Abstracts of the 25th Intersci. Conf. on Antimicrob. Agents Chemother., No. 793, p. 238, Minneapolis, Sept. $29 \sim$ Oct. 2, 1985

30) Henner, J. \& R. D. Sitrin: Isoelectric focusing and electrophoretic titration of antibiotics using bioautographic detection. J. Antibiotics 37: 1475 1478, 1984

31) Jeffs, P. W.; G. Chan, R. Sitrin, N. Holder, G. D. Roberts \& C. DeBrosse: The structure of the glycolipid components of the aridicin antibiotic complex. J. Org. Chem. 50: 1726 1731, 1985

32) Pitkin, D. H.; B. A. Mico, R. D. Sitrin \& L. J. Nisbet: Charge and lipophilicity govern the pharmacokinetics of glycopeptide antibiotics. Antimicrob. Agents Chemother. 29: 440 444, 1986

33) Lechevalier, H. A. \& M. P. Lechevalier: Introduction to the order Actinomycetales. In The Prokaryotes, Vol. 2. Ed., M. P. STARr et al., pp. 1915 1922, Springer-Verlag, Berlin, 1981

34) Lechevalier, M. P. \& H. A. Lechevalier: Chemical composition as a criterion in the classification of aerobic actinomycetes. Int. J. Syst. Bacteriol. 20: 435 443, 1970

35) Preobrazhenskaya, T. P.; M. A. Sveshnikova \& L. P. Terekhova: Key for identification of the species of the genus Actinomadura. The Biology of the Actinomycetes and Related Organisms 12:30 38, 1977

36) Athalye, M.; M. Goodfellow, J. Lacey \& R. P. White: Numerical classification of Actinomadura and Nocardiopsis. Int. J. Syst. Bacteriol. 35: 86 98, 1985

37) Tomte, K.; Y. Hoshino, T. Sasahira \& H. Kawaguchi: BBM-928, a new antitumor complex. II. Taxonomic studies on the producing organism. J. Antibiotics 33: 1098 1102, 1980

38) Gauze, G. F.; E. S. Kudrina, M. A. Sveshnikova, R. S. Ukholina, V. A. Filicheva, G. V. Gavrilina, M. G. Brazhnikova, I. N. Kovsharova, V. V. Proshlyakova, V. I. Ponomarenko, E. B. Kruglyak, V. A. Shorin, L. E. Goldberg, S. T. Filipposiants, T. Svetiana, O. K. Rossolimo, L. A. Averbukh, V. B. Zbarsky, L. S. Pokras \& M. K. Kudinova (Uni. Inst. New Antibiotiko): Anthracyclic antibiotic from Actinomadura carminata. Can. 995608, Aug. 24, 1976

39) Meyer, J.: New species of the genus Actinomadura. Z. Allg. Mikrobiol. 19: 37 44, 1979

40) Williams, D. H.; V. Rajananda, M. P. Williamson \& G. Bojesen: The vancomycin and ristocetin group of antibiotics. In Topics in Antibiotic Chemistry. Vol. 5. Ed., P. G. SAmmes, pp. 119 158, Ellis Horwood Ltd., Chichester, 1980

41) Malabarba, A.; P. Strazzolini, A. DePaoli, M. Landi, M. Berti \& B. Cavalleri: Teicoplanin, antibiotics from Actinoplanes teichomyceticus nov. sp. VI. Chemical degradation: Physico-chemical and biological properties of acid hydrolysis products. J. Antibiotics 37: 988 999, 1984

42) Heald, S. L.; L. Mueller \& P. W. JefFs: Teicoplanin $A_{2}$ : Structural analysis by 2D NMR. J. Mag. Res. 72: $120 \sim 138,1987$ and earlier references cited

43) Hunt, A. H.: Structure of the pseudoaglycon of A35512B. J. Am. Chem. Soc. 105: 4463 4468, 1983

44) Heald, S. L.; L. Mueller \& P. W. JeFFs: Actinoidins $A$ and $A_{2}$ : Structure determination using $2 \mathrm{D}$ NMR methods. J. Antibiotics 40:630 645, 1987

45) Chung, S. K.; S. L. Heald \& P. W. JEFFs: The dechloro aridicin antibiotics: preparation and characterization. J. Org. Chem. 52:1606 1610, 1987

46) Mueller, L.; S. L. Heald \& P. W. JefFs: The structure of glycopeptides and their complexes with putative cell wall precursors. Biophysical J. 49: 406a, 1986

47) Fesik, S. W.; T. J. O'Donnell, R. T. GAMPE, Jr. \& E. T. Olejniczak: Determining the structure of a glycopeptide-Ac $c_{2}$-Lys-D-Ala-D-Ala complex using NMR parameters and molecular modeling. J. Am. Chem. Soc. 108: $3165 \sim 3170,1986$ and earlier references cited

48) Coxon, B.: PMR evidence for the conformations of 1,2-O-benzylidene- $\alpha$-D-glucofuranose derivatives. Carbohydr. Res. 8: 125 134, 1968

49) Haasnoot, C. A. G.; F. A. A. M. De Leeuw, H. P. M. DE LeEuw \& C. Altona: The relationship between proton-proton NMR coupling constants and substituent electronegativities. Org. Magn. Res. 15: 43 52,1981

50) JACKMan, L. M. \& S. Sternhell (Ed.): Applications of nuclear magnetic resonance spectroscopy in organic chemistry. 2nd edition. Pergamon Press, Oxford, 1969

51) Borghi, A.; C. Coronelli, L. Faniuolo, G. Allievi, R. Pallanza \& G. G. Gallo: Teichomycins, new antibiotics from Actinoplanes teichomyceticus nov. sp. IV. Separation and characterization of the components of teichomycin (teicoplanin). J. Antibiotics 37: 615 620, 1984

52) Hunt, A. H.; R. M. Molloy, J. L. Occolowitz, G. G. Marconi \& M. DeBono: Structure of the major glycopeptide of the teicoplanin complex. J. Am. Chem. Soc. 106: 4891 4895, 1984

53) DePhillips, P. A.; A. J. Giovenella, S. F. Grappel, R. D. Hedde, P. W. Jeffs, L. B. Killmer, T. O. 
LiNDSEY, L. J. NisBet, G. D. Roberts, K. M. SNADER \& R. D. Srtrin: Isolation, structural studies and biological evaluation of the major and minor components of the aridicin (AAD-216) complex. Program and Abstracts of the 25th Intersci. Conf, on Antimicrob. Agents Chemother., No. 790, p. 237, Minneapolis, Sept. $29 \sim$ Oct. 2,1985 